Florida International University FIU Digital Commons

FIU Electronic Theses and Dissertations

University Graduate School

$11-1-2011$

\title{
Null Subject Behavior in the Attrition of Brazilian Portuguese
}

Tammer Castro

Florida International University, tcast010@fiu.edu

DOI: $10.25148 /$ etd.FI11120210

Follow this and additional works at: https://digitalcommons.fiu.edu/etd

\section{Recommended Citation}

Castro, Tammer, "Null Subject Behavior in the Attrition of Brazilian Portuguese" (2011). FIU Electronic Theses and Dissertations. 481. https://digitalcommons.fiu.edu/etd/481

This work is brought to you for free and open access by the University Graduate School at FIU Digital Commons. It has been accepted for inclusion in FIU Electronic Theses and Dissertations by an authorized administrator of FIU Digital Commons. For more information, please contact dcc@fiu.edu. 


\title{
FLORIDA INTERNATIONAL UNIVERSITY
}

Miami, Florida

\section{NULL SUBJECT BEHAVIOR IN THE ATTRITION OF BRAZILIAN PORTUGUESE}

\author{
A thesis submitted in partial fulfillment of the \\ requirements for the degree of \\ MASTER OF ARTS \\ in \\ LINGUISTICS \\ by \\ Tammer Castro
}

2011 
To: Dean Kenneth G. Furton

College of Arts and Sciences

This thesis, written by Tammer Castro, and entitled Null Subject Behavior in the Attrition of Brazilian Portuguese, having been approved in respect to style and intellectual content, is referred to you for judgment.

We have read this thesis and recommend that it be approved.

$\begin{array}{r}\hline \text { Ana Gouvea } \\ \hline \text { Phillip Carter }\end{array}$

Ellen Thompson, Major Professor

Date of Defense: November 1, 2011

The thesis of Tammer Castro is approved.

Dean Kenneth G. Furton
College of Arts and Sciences

Florida International University, 2011 


\section{DEDICATION}

I dedicate this thesis to my family and friends, in special my sister Dayanne Castro, and my fellow Linguistics T.A.'s, whose words of support and patience helped me throughout this arduous but pleasant journey. 


\section{ACKNOWLEDGMENTS}

I wish to thank the members of my committee for their patience and understanding. Their guidance has been highly appreciated. Dr. Phillip Carter's experience and knowledge of Brazilian Portuguese were extremely helpful. He was able to steer me in the right direction when I was not sure which route to take. Dr. Ana Gouvea's valuable contribution as a syntactician and native speaker of Brazilian Portuguese were also of fundamental importance in the development of this study.

Sincere thanks to the audiences at the following conferences for their questions and input: First International Linguistics Conference in Warsaw, Poland, Experimental Psycholinguistics - Formal Approaches at UNICAMP in Campinas, Brazil, $2^{\text {nd }}$ Annual Tampa Workshop on Syntax, Semantics and Phonology at University of South Florida in

Tampa, $35^{\text {th }}$ Annual Penn Linguistics Colloquium at the University of Pennsylvania in Philadelphia, and 2011 UIC Bilingualism Forum at the University of Illinois at Chicago.

I would also like to thank my advisor, Dr. Ellen Thompson, for trusting me and helping me accomplish this major goal. From the beginning, she has given me the tools I need, not only to finish this project, but also to prepare me for a higher step in my graduate career. Her words of wisdom always made me realize I could go further and achieve goals that were once thought as impossible. 


\section{ABSTRACT OF THE THESIS \\ NULL SUBJECT BEHAVIOR IN THE ATTRITION \\ OF BRAZILIAN PORTUGUESE}

by

Tammer Castro

Florida International University, 2011

Miami, Florida

Professor Ellen Thompson, Major Professor

The syntax of referential null subjects in Brazilian Portuguese (BP) is the topic of much recent work (Kato \& Negrão 2000; Ferreira 2000, 2004; Martins \& Nunes 2005, 2010; Modesto 2000; Rodrigues 2002, 2004). In light of the Interface Hypothesis (Tsimpli \& Sorace 2006), uninterpretable features such as purely syntactical elements should not undergo attrition. This study tests whether this hypothesis is valid in regard to the Null Subject behavior in the production of BP speakers under influence of L2 English. In order to do so, I conducted an experiment with monolingual BP speakers and bilingual (English/BP) speakers to establish a clear-cut comparison. The experiment consisted of an elicited production task and a grammaticality judgment task. The results of the data analysis show that BP speakers under influence of L2 English do seem to indicate attrition, thus encouraging further studies questioning the Interface Hypothesis. 


\section{TABLE OF CONTENTS}

CHAPTER

PAGE

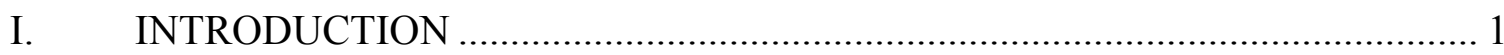

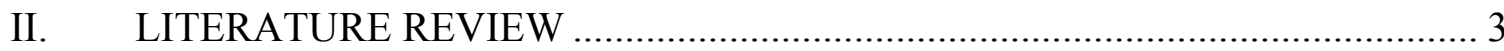

Interface Hypothesis of First Language Attrition ......................................... 3

Literature on First Language Attrition .................................................... 4

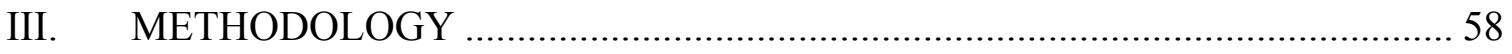

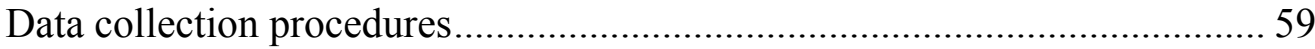

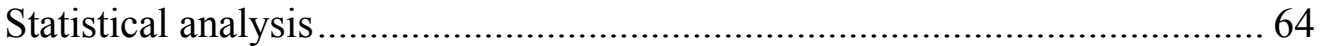

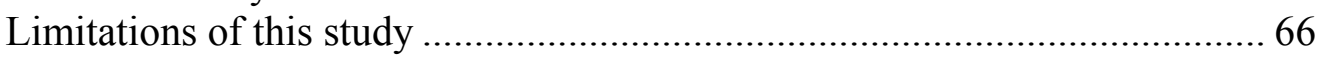

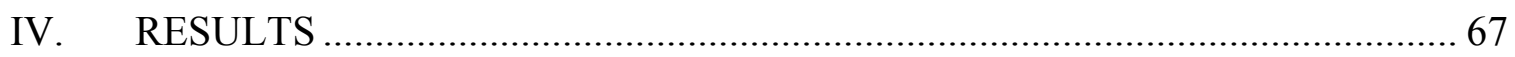

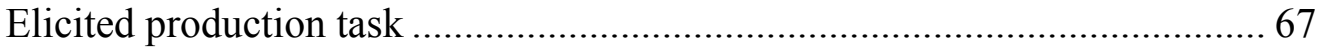

Grammaticality judgment task ....................................................... 73

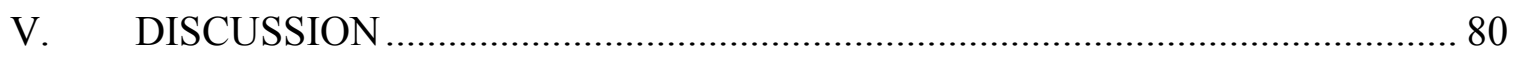

Restatement of aims and methodological approach of study...................... 80

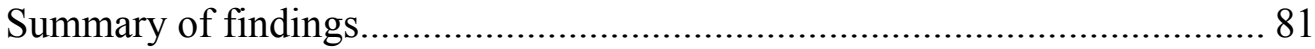

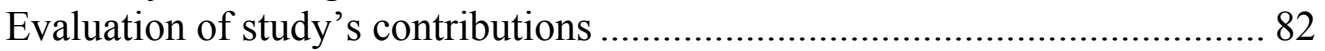

Recommendations for further research ............................................... 82

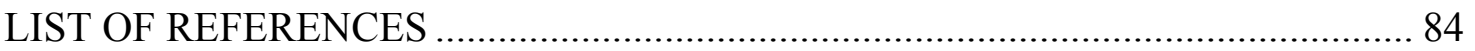

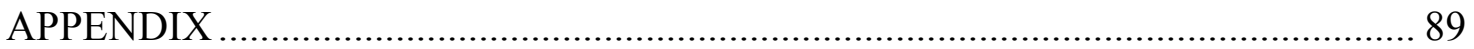




\section{I- INTRODUCTION}

The main goal of this study is to provide a comparative analysis involving two groups of Brazilian Portuguese (BP) speakers in order to determine whether syntactic attrition takes place. Köpke (2004) defines language attrition as "the loss of structural aspects of language, i.e., change or reduction in form". The Critical Period (CP) Hypothesis states that there is a period of time that is critical with respect to language acquisition (generally around puberty). It is assumed that late L2 learners (after the CP) are unable to attain native-like proficiency, but several studies have shown that there are cases of late L2 learners who are able to reach that goal, thus providing an argument against the $\mathrm{CP}$ Hypothesis. One interesting fact is that if one considers the $\mathrm{CP}$ as the borderline between attaining or not native-like pronunciation, it is important to point out that semantic relations are more dependant on late-maturing neural circuits, which leads to the conclusion that L2 learners may not be likely to lose their foreign accents after the $\mathrm{CP}$, but will be more likely to master vocabulary and grammatical relations than a child under the age of 12, for example (Köpke 2004).

The findings of this study will test the validity of the Interface Hypothesis of Language Attrition, which suggests that syntax-discourse interface areas are more complex and more prone to L1 attrition, whereas syntactic features will remain unatrrited regardless of L2 interference (e.g., Sorace, 2000, 2005; Tsimpli and Sorace, 2006; Tsimpli et al. 2004).

In order to test for attrition, it is fundamental that the subjects tested have been outside their L1 environment for a certain length of time, and that they left their home 
country after the $\mathrm{CP}$, which rules out any possibility of them being native speakers in their L2 as well. I conducted elicited production and grammaticality judgment tasks in these domains in native monolingual BP speakers, and in native BP speakers living in the United States for over seven years. In the elicited production task, the subjects are given a comic strip which is very popular among Brazilians. The speech bubbles are removed to assure that the subjects will not include any of those words in their oral production. They are then asked to summarize the actions of the characters and the sequence of events as they take place in the story, while their voices are being recorded. The grammaticality judgment task consists of fifty sentences, among which twenty-four fillers. The subjects are asked to judge each sentence according to its acceptability in their dialect.

This thesis consists of five chapters. Following this introduction, Chapter II presents a review of the literature and research that motivates the research questions addressed in this study. It also provides a section with a review of the literature on BP null subject constructions. Chapter III shows the methodological approach used in this research study. Key findings from the data analysis are presented and discussed in Chapter IV. A summary of the study findings with reference to the research questions and how the results relate to the Interface Hypothesis is included in Chapter V, along with the limitations of this study and recommendations for further research. 


\section{II - LITERATURE REVIEW}

In this chapter, I present (i) a review of the literature on the syntax of first language attrition and (ii) a review of the literature on the syntax of the null subject construction in Brazilian Portuguese.

First Language Attrition is understood in the present work to be "the nonpathological erosion of previously acquired L1 properties (lexical, syntactic, semantic/pragmatic) that results from intense contact with a dominant second language" (e.g., Gürel 2004; Köpke and Schmid 2004; Montrul 2002; Schmid 2002; Seliger 1996; Silva-Corvalán 1991; Sorace 2004). (qtd. in Cuza, 2010).

Research on first language attrition indicates that significant changes occur in the representation of the native language (L1) under the influence of a non-native language (L2). Previous research has aimed to determine the ways in which a native language changes under influence from a foreign language. A dominant view in the literature on L1 attrition is known as the Interface Hypothesis, according to which syntax-discourse interface areas (interpretable domains) are more complex and more permeable to L1 attrition. In contrast, purely syntactic features will remain unproblematic to L2 interference and therefore spared from L1 attrition (e.g., Sorace, 2000, 2005; Tsimpli and Sorace, 2006; Tsimpli et al. 2004).

\section{Interface Hypothesis of First Language Attrition}

Changes in L1 syntax are restricted to areas of the grammar where the syntax interfaces with interpretable domains; discourse/pragmatics or semantics (see Sorace 2000; Tsimpli, Sorace, Heycock, and Filiaci 2004). We will return to a detailed 
discussion of the Interface Hypothesis of First Language Attrition in later chapters of this thesis.

\section{Literature on First Language Attrition}

\subsection{Changing the first language in the L2 user's mind - Vivian Cook}

In his introductory text on attrition, Cook (2003) shows that the first language of people who know other languages differs from their monolingual peers in diverse ways. He also argues that when a person knows more than one language, those languages work together in a "super-system" rather than in isolation. Multi-competence is defined as the knowledge of two or more languages in one mind.

Cook mentions that L2 users and monolinguals differ in several ways. One way in which this difference can be shown is that the L2 user may have a difference in the register of language used, if it is highly influenced by textbook formalities. A dialogue in English involving two L2 users or an L2 user and a monolingual will be different from a dialogue involving two native speakers. Another difference is that the L2 user's knowledge of the second language is typically not identical to that of a native speaker. Because the L2 learner already has knowledge of their first language while acquiring the second, the L1 grammar remains present, and therefore the L2 learner possesses two grammatical systems, which may be in competition in their minds. Since the monolingual has knowledge of only one grammatical system, there is no other system that may influence this grammar - therefore, their grammar is bound to be different from that of an L2 user. 
Cook discusses the Separation Model, according to which the L2 user speaks only one language or the other, with no apparent connection between them, with both languages stored in isolated compartments in the speaker's brain. In contrast to this, he mentions the Integration Model, which suggests that both languages form one single system, in which there is only one lexicon where words from both languages are stored. Cook claims that neither model is accurate, in the sense that there cannot be total integration, since the speakers are able to keep both languages apart. Likewise, the Separation Model is implausible because the languages are stored in the same speaker's brain, and there does seem to be influence of one language on another. Cook proposes the Linked Languages Model, which is essentially a mix of both models, according to which the two language components are represented separately but are able to interact with each other. For example, some of the vocabulary may be shared, as well as some phonological and syntactical patterns.

Surprisingly, according to Cook, attrition is not necessarily to be viewed as a loss. One's L2 can influence his or her L1 in a positive way. For example, he claims that it has been shown that Hungarian children who know English use more complex sentences in Hungarian than the ones who do not. This leads to the interesting conclusion that bilingual children have more precocious metalinguistic skills than their monolingual peers (Bialystok, 2001).

In terms of methodology, Cook claims that care should be taken in the experimental use of the term "monolingual". He notes that when looking for monolingual research subjects, with the stipulation that they have to have no knowledge of a second language, one can come across individuals who have received no formal instruction. Such 
individual would be a true monolingual, but because of the lack of formal instruction, his or her L1 may not necessarily have the identical grammatical patterns as educated speakers of the language that are to be analyzed in the study.

One possibility that Cook suggests is to compare minimal versus maximal bilinguals, i.e., subjects who have had the least possible exposure to another language versus those who have studied it at an advanced level. It is also fundamental to control for these different groups in experimental work, to be able to conclude that the results are as accurate as possible.

\subsection{Neurolinguistic Aspects of Attrition - Barbara Köpke}

In her paper, "Neurolinguistic Aspects of Attrition", Barbara Köpke discusses in some detail two issues that are of particular importance when it comes to attrition: the role of the subject's age and the influence of L2. The author presents an informative overview of the Critical Period Hypothesis (CPH), and also discusses whether attrition occurs because of lack of L1 use or because of its replacement by the L2 structures.

Köpke notes that the phenomena of language change, shift and death normally take place across generations, whereas attrition occurs within one generation. It is important to clarify the difference between language death and language attrition. Language death occurs when the level of linguistic competence possessed by speakers of a certain language is gradually reduced to the point where there are no native speakers of that language. Attrition consists of the loss of structural aspects of language, while language shift is a loss of functional aspects. A clear example of language attrition is a situation where the speaker of a given language becomes fluent in another language to the 
extent that some structural features which are exclusive to the L2, such as preposition stranding in English or subject-verb inversion in Spanish, start appearing in the native speaker's L1 production. For example, English allows preposition-stranding, as in (1a), whereas Spanish does not allow this construction, but instead requires the prepositional phrase to move as a unit, as shown in the contrast between (2a) and (2b):

(1). a. Where are you from?

b. ?? From where are you?

(2). a. * ¿Donde eres de?

Where are (you) from

"Where are you from?"

b. ¿De donde eres?

From where are (you)

"Where are you from?"

(3). a. ${ }^{*}$ ¿Que es el libro sobre?

What is the book about

"What is the book about?"

b. ?Sobre que es el libro?

About what is the book

"What is the book about?"

Native speakers of Spanish who have undergone influence from their L2 English may produce sentences such as (2a) and (3a) above, which follow the L2 syntactical pattern (see Depiante and Thompson (2010) for discussion of this construction in the heritage speaker population). Native monolingual speakers of Spanish do not produce 
sentences such as (2a) or (3a), and we can therefore conclude that such occurrences are the result of the influence of the L2 grammatical patterns. On the other hand, to illustrate language loss, one can imagine a community where only one language is spoken. The members of that community originally become bilingual because of external factors such as immigration, and gradually the speakers start using their L2 more often than their L1, which could then result in language death.

Some of the external factors that Köpke mentions are normally associated with attrition are age, education level, emigration length and amount of contact with L1; some internal factors are emotion or attitudes and motivation. Importantly, attrition is selective and does not involve all aspects of a language the same way, a point that we will return to below.

Köpke claims that linguistic knowledge of a bilingual speaker is not the sum of the knowledge of two monolinguals. She argues that bilinguals have been shown to be slower than monolinguals on at least some language tasks, such as naming, lexical decision and sentence processing. The reason for such differences has been attributed to difficulties the bilingual has in selecting a word from either language inventory, or in difficulty controlling both language systems. The weaker, non-dominant language is usually the L2 in late bilinguals, but even in late bilinguals the dominance pattern can be reversed, in which case the L2 becomes the dominant language. Bilinguals may reach a point where processing of the L1 is not only slowed down, but where it becomes more and more influenced by the L2 structures.

The Critical Period Hypothesis suggests that there is a fundamental connection between age and the ability to acquire a language. It is generally assumed that late L2 
learners, who start acquiring the language into adulthood, are unable to attain native-like proficiency, but several studies have shown that there are cases of late L2 learners who are able to reach that goal, thus falsifying the $\mathrm{CP}$ Hypothesis. One interesting claim that Köpke introduces is that if one considers the $\mathrm{CP}$ as determining the borderline between attaining or not native-like pronunciation, it is important to note that semantic relations are more dependent on late-maturing neural circuits, which leads to the prediction that L2 learners may not be likely to lose their foreign accents after the $\mathrm{CP}$, but will be more likely to master vocabulary and grammatical relations than a child under the age of 12 , for example. Köpke argues that the age of acquisition of L2 is intrinsically related to the linguistic knowledge of the learner. Children can easily acquire more than one language since their brains are still malleable and therefore they are more able to successfully acquire different language structures.

Köpke notes, "The linguistic domain in which most L2 influence has been reported is doubtlessly the lexicosemantic domain. L1 lexical retrieval was also found to be influenced by L2 characteristics." (p.19). The paper concludes that "educational level can be linked to the amount of declarative knowledge of a language". It is assumed that two individuals who are the same age but have different educational levels will use language differently, because they receive different inputs. The author also concludes that "[t]he age effect in attrition is probably related to maturational constraints for language acquisition and growing automaticity. Frequency of use has direct consequences on activation levels and thus influences the balance between the two languages", which accounts for why bilinguals may have trouble accessing words which are rarely used. 
The conclusion of this paper that age is an important factor in attrition is controlled for in the current study, and will be discussed in later chapters of this thesis. All of the participants are younger than the age at which attrition occurs naturally, and are well over the age of the Critical Period. Further, the discussion of the relevance of educational level is also controlled for, since all of our subjects have received college education. These two factors thus provide more homogeneous results as far as linguistic knowledge goes.

\subsection{L1 Persian Attrition - Hamideh Jamshidiha \& Hamideh Marefat}

Jamshidiha \& Marefat (2005) focus on investigating first language attrition in Persian speakers of English as a Second Language. In order to do that, the participants were divided in three groups: monolinguals, early bilinguals and late bilinguals. The syntactic features chosen for this study were adverb position, relative clauses and prodropping (main differences between Persian and English). The author introduces the study by giving some theoretical background on attrition and a series of hypotheses that will later be used to refute/support the results found. They consider age and length of stay determining factors when analyzing language attrition, as such factors are intrinsically related to how one's brain reacts to the new language and how much of one's L1 is being used.

The participants were first given a linguistic background questionnaire. Then they took a grammaticality judgment test in order to determine the acceptability of certain sentences in Persian. An attrited speaker might believe that a sentence such as "*This is the instrument that you had ordered it" is unacceptable in Persian (which is not the case) because of the influence of the L2 English. 
The results show that the late bilinguals had not lost their preference for the prodrop Persian structure, despite the amount of time they had lived in an English speaking country, which gives support to the Regression Hypothesis, according to which language components may be lost in the reverse order in which they were acquired. The results also proved that early bilinguals suffered more attrition than late bilinguals, which was also expected.

The advantages of the study are that the author analyzes monolinguals versus bilinguals, and then further splits the bilinguals into two groups and analyzes that contrast as well. Length of stay is taken as the dividing line between late and early subjects of attrition - eight years is the minimum as a solid pattern for attrition.

\subsection{The Syntax of Null Subjects in L2 Spanish: Comparing Two L2} Populations under Different Exposure - Jason Rothman \& Michael Iverson

Rothman and Iverson discuss, in this article, the model of language learning that is crucial to the understanding of language attrition. These researchers investigate how the study-abroad experience, or increased exposure to native input, is beneficial in terms of the acquisition of new functional features needed for parameter resetting. The paper uses a previous study by Isabelli (2004) as reference for their research study. The hypothesis suggested by Isabelli is that such immersion is beneficial to learners for the resetting of the NSP (Null Subject Parameter), which Rothman and Iverson

The NSP divides languages into pro-drop languages (such as Spanish and Romance languages in general) and non-pro-drop (such as English). Typical Null Subject Languages have null expletive subjects and null pronominal subjects, as in the Spanish examples shown below: 
(4) Estaba lloviendo.

Was raining

'It was raining.'

(5) Salí de la casa.

Left-I from the house

'I left the house.'

(6) Yo salí de la casa.

I left from the house

'It was I who left the house.'

Typical Non-Nul Subject Languages do not follow the same pattern. These languages have overt expletive subjects and overt pronominal subjects, as shown in the English examples below:

(7) It was raining.

(8) I left the house.

(9) *Left the house.

Brazilian Portuguese, as claimed by Duarte (1995), seems to behave in a transitional way in the sense that some of its pro-drop properties have been or are being lost. Brazilian Portuguese has null expletive subjects, matrix null subjects as instances of topic deletion (Ferreira 2000 and Modesto 2000) and third person referential overt subjects in main clause (Rodrigues 2004).

(10) Estava chovendo.

Was raining.

'It was raining.' 
(11) Saí da casa.

Left-I from-the house

'I left the house.'

(12) Ele saiu da casa

He left from-the house

'He left the house.'

There is some discussion in the literature about how not all pro-drop languages function the same way with respect to overt expletive subjects. Rothman and Iverson mention European Portuguese and Galician (as discussed in Arteaga 1994; Raposo and Uriagereka 1990) as examples of languages that allow for overt expletive subjects, in spite of being pro-drop languages in other respects. In addition, there are studies which confirm that some non-pro-drop languages employ null expletive subjects (such as German and Swedish). These data support the claim that cross-linguistic properties that co-occur in Spanish and English do not necessarily derive from the resetting of the NSP, since such properties were initially present in the learner's L1.

Rothman and Iverson tested a group of eight native speakers of Spanish, a set of thirty study-abroad L2 learners and twenty-four so-called "classroom" L2 learners (the ones who did not study abroad). Both groups of L2 learners were tested after five months of studying the target language. One group was studying university-level Spanish in the United States, and the other group was studying in Madrid, Spain for the same amount of time.

A grammaticality judgment test was conducted to test for the properties examined by Isabelli, namely co-ocurrence of null and overt subject pronouns in tensed clauses 
(13a), obligatory null-expletive subjects (13b), free subject-verb inversion (13c) and no that-trace effects (13d).

(13a) Yo hablo francés. Pro hablo francés.

I speak French. pro speak French.

'I speak French.'

(13b) pro hace mucho viento. *Ello hace mucho viento.

pro make much wind. It make much wind.

'It is very windy.'

(13c) Ellas se fueron. Se fueron ellas.

They themselves left. Themselves left they.

'They left.'

(13d) ¿Quién crees que no sabe bailar? ¿¿Quién crees no sabe bailar?

Who believe-2PSg that no know dance / Who believe-2psg __ no know dance ‘*Who do you believe that can't dance/ Who do you believe can't dance?'

A second test was applied to check for the instantiation of the Overt Pronoun Constraint (OPC) proposed by Montalbetti (1984). The OPC states that in null-subject languages, an internal co-reference interpretation between overt embedded subjects and matrix clausal subjects is not possible, as seen below:

(14) [Cada estudiante $\mathrm{i}_{\mathrm{i}}$ sabe que é $\mathrm{*}_{\mathrm{i} j \mathrm{j}}$ debe estudiar mucho para pasar el examen. Each student knows that he must study much to pass the exam 'Every student knows that he must study hard to pass the exam.'

The authors conclude that there were no significant changes in performance within the five months of learning. Both L2 groups had previous knowledge of null- 
subjects prior to the study, and the study-abroad experience did not prove effective with respect to acquisition of these syntactic properties. The findings also show that the resetting of the NSP is possible given classroom type input, since the classroom learners were successful in learning the properties of the Null Subject Parameter.

The authors do agree that study-abroad programs benefit L2 learners in a broad sense. Culturally and linguistically, immersion in an L2 language environment has been proven effective by many authors. However, Rothman and Iverson claim that it is not clear whether such exposure is profitable in terms of the acquisition of new L2 features.

2.5 Heritage Speaker Competence Differences, Language Change, and Input Type: Inflected Infinitives in Heritage Brazilian Portuguese - Jason Rothman

Although it does not examine attrition per se, Rothman's (2007) work on Brazilian Portuguese is nevertheless relevant for the current study. The study "Heritage Speaker Competence Differences, Language Change, and Input Type: Inflected Infinitives in Heritage Brazilian Portuguese", focuses on one syntactic feature of Brazilian Portuguese - inflected infinitives, and how they, by supposition, have disappeared from the non-standard dialects of Brazil.

Sentence (16) is ungrammatical in Brazilian Portuguese, since the verb "comprar" is not inflected. This form requires the subject of the embedded clause to be PRO, referring thus back to the subject of the main clause "Eu" (I). With the $3^{\text {rd }}$ person plural pronoun "eles", the grammatical verb form would be the inflected "comprarem".

(15) $\mathrm{Eu}_{\mathrm{i}}$ lamento eles / pro* $*_{\mathrm{i} j}$ nao comprarem a casa.

I regret they / pro $*_{i j}$ not to buy the house.

'I regret (them) not buying the house.' 
(16) *Eu lamento eles não comprar a casa.

I regret they not to buy the house.

'I regret (them) not buying the house.'

(17) $\mathrm{Eu}_{\mathrm{i}}$ lamento $\mathrm{PRO}_{\mathrm{i}}$ não comprar a casa.

I regret PRO not to buy the house.

'I regret not buying the house.'

Pires $(2002,2006)$ claims that inflected infinitives are only introduced in formal education, and therefore it is predicted that Brazilian monolinguals who do not receive formal education, as well as heritage speakers who do not receive instruction in Portuguese, do not have knowledge of inflected infinitives. On the other hand, L2 learners and educated native controls are predicted to have acquired inflected infinitives, following the claim that literacy plays a major role in the acquisition of this feature in the syntax of literate Brazilian Portuguese.

Rothman argues that although heritage speakers may be very orally proficient, they may lack functional literacy, which may result in a number of severe linguistic and sociolinguistic consequences. It is important to point out that literacy is not related to the ability to acquire foreign languages; multilingualism in illiterate societies shows that it can be possible to learn multiple languages without being literate in any.

Pires claims that inflected infinitives do not exist in non-standard varieties of Brazilian Portuguese (but remain in the standard form and in both colloquial and standard form in European Portuguese). Rothman investigates whether heritage speakers recognize this construction as part of their dialect, and what the implications of this are. He points out that all languages with inflected infinitives are "null subject" languages, but the 
reverse is not true: European Portuguese, for example, is a language with inflected infinitives and is also a "null subject" language, but languages such as Spanish and Italian allow null subjects but do not have inflected infinitives. In fact, most pro-drop languages do not have inflected infinitives, so Portuguese is marked in that sense.

In order to conduct his experiment, a grammaticality judgment test was used with the purpose of checking for distributional restrictions on the use of inflected infinitives. Examples of two of the sentences used in this task are as follows:

(18) O João lamenta as meninas não terem chegado.

The João regrets the girls not have-INF-3PPL arrived

"João regrets the girls not having arrived."

(19) O Marco afirma não conhecermos a cidade.

The Marco claims not know-INF-3PPL the city.

'Marco claims that we do not know the city.'

Next, a context-matching sentence task was given to test for knowledge of interpretive restrictions on inflected versus uninflected infinitives. For example:

\section{a. Sloppy reading context}

Quando o nosso pai morreu a minha irmã chorou em frente de todos. Por isso, ela se sentia um pouco envergonhada. Mais tarde, ela me disse que estava muito orgulhosa de mim porque pensou que eu era muito forte. Ela nunca soube que eu tinha chorado também porque ninguém me viu chorar.

When our father died my sister cried in front of everyone. As a result, she felt a little embarrassed. Later, she told me that she was very proud of me because she 
thought I was very strong. She never knew that I had also cried because nobody saw me cry.

Which sentence(s) is (are) logical given the context?

i. Eu lamento ter chorado e a minha irmã tambem.

I regret have-INF cried and the my sister too

'I regret having cried and my sister does too

ii. Eu lamento termos chorado e a minha irmã tambem.

I regret have-INF-1PL cried and the my sister too

'I regret our having cried and my sister does too

b. Strict reading context

Ontem era o dia da partida de futebol mais importatnte do ano. Eu pensei que fôssemos ganhar, mas a gente perdeu. Agora estou muito triste e não quero sair. Realmente, eu não posso acreditar que não ganhamos. A minha namorada está muito triste também porque agora eu não quero sair de casa.

Yesterday was the most important day for soccer of the whole year. I thought we were going to win, but we lost. Now I am very sad and I don't want to go out. Truly, I just can't believe that we did not win. My girlfriend is also quite sad because now I don't want to leave my house.

Which sentence(s) is (are) logical given the context?

i. Eu lamento ter perdido e a minha namorada também.

I regret have-INF lost and the my girlfriend too

'I regret having lost and my girlfriend does too.'

ii. Eu lamento termos perdido a minha namorada também. 
I regret have-INF-1PL lost and the my girlfriend too

'I regret our having lost and my girlfriend does too.'

Eleven heritage speakers participated in the research. For the grammaticality judgment task, they were given a set of sentences and had to judge whether or not those sentences were acceptable to them, and for the unacceptable ones, they had to come up with their acceptable version of them.

Rothman concludes that heritage speakers differ from native speakers educated in Brazilian Portuguese in that they do not acquire inflected infinitives, which supports the claim that this construction is no longer present in BP primary linguistic data (Pires, 2002, 2006). In this paper, he shows how heritage speakers can serve as a bridge to investigate the role that literacy has on linguistic competence. Since they have little or no formal instruction in the target language, some of the syntactic features may have never been acquired.

In the present project, I will investigate the properties that Rothman investigates as well. In that sense, it is relevant to investigating the attrition of the null subject properties of Brazilian Portuguese, since heritage speakers provide another source for potential variation in the acquisition of the null subject properties of Brazilian Portuguese.

2.6 Syntax-Pragmatics Interface: Brazilian-Portuguese L2 Acquisition of English - Silvana Pacheco and Suzanne Flynn

Pacheco and Flynn (2006) present the results of a previous study and an ongoing study, the former regarding the $\mathrm{L} 2$ acquisition of third person singular object pronouns by 
speakers of Brazilian Portuguese, and the latter focusing on the L2 acquisition of the grammatical properties of English subjects and objects by adult speakers of Brazilian Portuguese (BP).

Considering the fact that $\mathrm{BP}$ is a Romance language, one might expect that it should possess the same syntactic features as Spanish and Italian, for example. However, many authors have argued that BP is losing some of those patterns. Duarte (1995) claims that $\mathrm{BP}$ is becoming a non-pro-drop language, while maintaining some properties of prodrop languages. The authors give a brief overview of how pro-drop occurs in BP. According to Pacheco and Flynn, null subjects are preferred with third person singular in embedded context, i.e., as subjects of embedded clauses in Brazilian Portuguese. In European Portuguese (EP); however, such feature is mandatory, in general:

(20) Ele $e_{\mathrm{i}}$ sentiu que pro $_{i} /$ ele era o único ali novo. BP

$H e_{\mathrm{i}}$ felt that $\mathrm{pro}_{i} /$ he was the only there young.

('He realized that he was the only young man there'.)

(21) Ele $e_{\mathrm{i}}$ sentiu que $\mathrm{pro}_{i}$ era o único ali novo. EP $H e_{\mathrm{i}}$ felt that $\mathrm{pro}_{i}$ was the only there young. ('He realized that he was the only young man there'.) As for expletive null subjects, BP behaves similarly to other Romance languages in the sense that expletive null subjects are mandatory, as shown below:

(22) ec Choveu o dia todo.

ec Rained the whole day.

('It has rained the whole day') 
*Ele choveu o dia todo.

$\mathrm{He} / \mathrm{It}$ rained the day whole

It rained the whole day

According to Duarte, BP is becoming a non-pro-drop language, as shown by the fact that BP speakers prefer overt subjects in $1^{\text {st }}$ and $2^{\text {nd }}$ person singular, which is not typical in Romance languages (including European Portuguese).

(24) $E u$ acho muito engraçado quando $e u$ lembro o modo que $e u$ fui criada.

BP

$I$ think very funny when $I$ remember the way that $I$ was educated.

('I think it's very funny when I remember the way I was brought up.')

(25) pro acho muito engraçado quando pro lembro o modo que pro fui criada. EP pro think-1psg very funny when pro remember-1psg the way that pro was-1psg educated.

('I think it's very funny when I remember the way I was brought up.')

Pacheco's previous L2 research had as participants 145 adolescent and adult learners of English as a Foreign Language, divided into beginner, basic, intermediate and advanced levels. The test used consisted of a set of sentences which needed to be completed by the participants, using the targeted verb plus a model. There were two versions of the test, one for advanced learners only (26) and another one for the other groups (27):

(26) If you met Mary again, (invite).

(27) If you meet Mary again, (invite).

The results of this study conclude that there needs to be a specific context for deletion of the object to occur [-animate, -specific]. Brazilian Portuguese is a language 
which allows for deletion of the pronominal object in certain cases, and therefore these bilinguals were expected to follow this pattern in English as well (which would then indicate interference of the L1). The beginner group had a high frequency of null objects in the context $[+$ anim, + spec], which was unexpected as object deletion is almost nonexistent in this situation. Intermediate and advanced students did not have trouble with the usage of the pronominal forms in English, due to their knowledge of the syntactical L2 pattern. The author concludes that there is "differential L2 development of syntactic and pragmatic knowledge of English". In this case, syntax and pragmatics are intrinsically dependent upon each other.

Pacheco and Flynn also discuss their recent experimental work, which tests for the development of syntax and pragmatics in the adult L2 acquisition of English by L1 BP speakers. The test focuses on the similarities and differences between English and BP in terms of the use of null subjects and objects.

Eleven college students participated in this study. The participants were all native speakers of BP at different levels of proficiency in English. Three different tasks were applied, but they chose to focus on the grammaticality judgment task for this article. The grammaticality judgment task was divided in $[+$ pragmatic context] and [-pragmatic context]. This division was made to test whether or not the participants' judgments were affected by the pragmatics of their L1, more specifically deletion of a subject or an object when the context allows for the recovery of the deleted argument, as shown below:

[+pragmatic context]

(28a) The intelligent student studies at a public school in New York. *Goes to school with an elderly woman on Mondays and Fridays. 
Sentence (28a) is unacceptable in English but allowed in BP by the presence of the pragmatic context.

[-pragmatic context]

(28b) * Has a full time position at the famous Harvard School of Law.

Without a pragmatic context, sentence (b) is unacceptable both in English and BP.

The authors state that "The presence of a [+pragmatic context] might lead learners to accept ungrammatical sentences in English, such as a null subject sentence as (28a) above, because this null argument could be interpreted in such a context in BP. For the same reason, the absence of a pragmatic context might lead learners to correctly reject ungrammatical null subject sentences such as (28b)."

The data analyzed suggest that even though BP and English behave differently with respect to the Null Subject Parameter (NSP), learners develop their L2 grammars independently of their L1 grammars. The findings show that in spite of having syntactic knowledge of BP null-subject behavior, the L2 learners are aware of the difference in the English structure, and therefore correctly include the expletive subject when required by the rules of their English L2 grammar. The findings also confirm the hypothesis that a pragmatic context would influence the learners' judgment of acceptance of a null or overt subject in a matrix clause. We will see that consideration of the factors of pragmatic context and differences between null pronominal and expletive subjects is important to distinguish the behavior of speakers of Brazilian Portuguese who have influence from English, and speakers of Brazilian Portuguese who do not. 
2.7 First Language Attrition and Syntactic Subjects: a Study of Greek and Italian Near-Native Speakers of English - Ianthi Tsimpli, Antonella Sorace, Caroline Heycock and Francesca Filiaci

The paper that has the most relevance to the current project is, "First Language Attrition and Syntactic Subjects: a Study of Greek and Italian Near-Native Speakers of English", by Ianthi Tsimpli, Antonella Sorace, Caroline Heycock and Francesca Filiaci. The main point of this paper is to analyze attrition in two different groups of bilinguals (Greek/English and Italian/English) and show the comparison between both groups once the results are given. The authors take into consideration particular features of Greek and Italian that are not present in English, such as pro-drop (both Greek and Italian are nullsubject languages) and postverbal subjects, which are also allowed in Brazilian Portuguese (but it seems to me that there are some constraints as far as the usage of postverbal subjects in $\mathrm{BP})$.

The hypothesis of the authors is that syntactic attrition primarily affects morphosyntactic features that are interpretable at the LF interface, but leaves unaffected uninterpretable features, which regulate parametric syntax (Sorace, 2008) (see discussion of the Interface Hypothesis above). In other words, attrition should occur when both L2 and L1 have conflicting options which are accessible at the interface. If the speaker finds no "optional syntax" in the L2, attrition should not occur.

The participants of the study were divided in four groups, two bilinguals and two controls, with roughly twenty people in each group. The subjects were given a headlines task, which consisted of the production of a complete sentence with given phrases along with a picture. The aim was to test the use of preverbal and postverbal subjects. 
Naturally, the controls preferred the postverbal subjects. A picture verification task was given as well. For this one, the participants had to match a sentence with the correct picture out of three pictures shown. The authors argue that the results prove that Italian and Greek controls choose postverbal over preverbal subjects for different reasons, the former due to (in)definiteness of the subject and the latter for no apparent reason. Attrition was found in the production of preverbal subjects in the Greek group, whereas Italian speakers show attrition effects in the interpretation of overt pronominal subjects. However, these authors argue that there is no attrition of the uninterpretable features of subjects; the changes in attrition were the result of an alteration of the semantic features such as topic and focus.

The paper is especially relevant to the current project. As far as the features chosen to be analyzed, because BP and Italian are Romance languages, they behave similarly when it comes to postverbal subjects; however, there are some other constraints in BP that Italian does not seem to follow. Although I will not be examining postverbal subjects in particular, the sentences that are produced by the subjects could generate discussion of their hypothesis about this construction.

\subsection{On the attrition of the Spanish Present Tense - Alejandro Cuza}

The purpose of the paper "On the Attrition of the Spanish Present Tense", by Alejandro Cuza, is to demonstrate the results of a study which investigates to what extent Spanish immigrants find problematic the ongoing property of the Spanish Present Tense (discussed in more detail below), which is not present in English, and for this reason English speakers make use of the Present Progressive Tense for such purpose. Cuza 
illustrates the difference between the properties of both languages, as far as the Present Tense goes, with these examples:.
a. (English) Rose plays tennis.
right now\#
tennis player $\sqrt{ }$
b. (Spanish) Rosa juega al tenis.
right now $\sqrt{ }$
tennis player $\sqrt{ }$
c. (English) Rose is playing tennis.
right now $\sqrt{ }$
tennis player\#
d. (Spanish) Rosa está jugando al tenis.
right now $\sqrt{ }$
tennis player\#

As shown above, the Present Tense in English does not carry the ongoing meaning, only the habitual interpretation that Rose plays tennis (29a), whereas in Spanish, "Rosa juega al tenis" could mean that she plays tennis every now and then or that she is playing at the moment of speech.

The Interface Hypothesis of First Language Attrition, as discussed above, claims that uninterpretable features do not undergo attrition, while interpretable features are vulnerable to attrition. On the basis of the comparison above, the prediction that this hypothesis makes is that long-term Spanish immigrants should have difficulty with the ongoing pattern of the Present Tense in Spanish, as English lacks that property and the semantic values associated with the Present Tense are different in both languages. He also hypothesizes that the subjects would not have a problem with the Progressive aspect or the generic interpretation of the Present Tense, as both features are present in the L2 (English).

Thirty-nine subjects participated in this study, being nineteen long-term immigrants and twenty bilingual and monolingual Spanish speakers who served as a control group. The study was restricted to Caribbean immigrants to avoid any dialectal 
differences. Cuza established a minimum of ten years of immersion in the L2 environment as one of the main criteria because he believed that to be a reasonable time after which attrition emerges (following Gurel, 2004).

The test was divided into three tasks: an acceptability judgment task, a listening truth value judgment task and an elicited production task. The first task consisted in their judgment of the acceptability of sentences in their dialect. They were asked to read the sentence and then choose from a set of five options (odd, slightly odd, I don't know, more or less fine or perfectly fine).

For this task, twenty test items (five tokens per condition) and twenty fillers were used. An example of a scenario supporting an ongoing situation is shown below:

(30) Giselle is very happy today and she has started to sing her favorite song.

a. Giselle canta su canción preferida en estos momentos. [pres. ong.]

Giselle sings-PRES her song favorite right now

"Giselle is singing her favorite song right now."

-2 (odd) -1 (slightly odd) 0 (I don't know) 1 (more or less fine) 2 (perfectly fine)

b. Giselle está cantando su canción preferida en estos momentos. [prog. ong.]

Giselle is singing-PROG her song favorite right now

"Giselle is singing her favorite song right now."

-2 (odd) -1 (slightly odd) 0 (I don't know) 1 (more or less fine) 2 (perfectly fine)

Since the ongoing feature of the Simple Present does not occur in English, the expected results, on the basis of the Interface Hypothesis, are that the participants would judge sentences such as (a) as acceptable. The ongoing feature of the Simple Present is purely 
syntactic, and therefore should not be affected by the L2 grammar, according to the Interface Theory.

The truth value task was structured as follows: the participants were given a scenario and then a sentence related to this scenario. To avoid priming effects, the scenarios in both tasks were presented in English. On the basis of that, they had to judge whether the sentence was true or false, as shown in the example below:

(31) Miguel does not like to run. However, today it's a nice sunny day and he has started to run around the park.

$\begin{array}{lll}\text { Miguel corre por el parque. } & \text { Yes } \quad \text { No [pres. ong] }\end{array}$

Miguel runs-PRES for the park.

"Miguel is running around the park."

The context above is an example of the ongoing feature of the Present Tense. Speakers who are transferring from English are expected to judge this sentence as false, since English does not allow for an ongoing meaning. Therefore, they would interpret this sentence as "Miguel habitually runs around the park", and since the context is, "Miguel does not like to run", they should report that the sentence is false.

The elicited production task consisted of an oral narration of the story Frog Goes to Dinner. Participants were shown only black-and-white images of the story, and were then asked to narrate the story using the Present Tense. Cuza predicted that adult immigrants would prefer not to use the Present Tense with an ongoing interpretation, since it is not a feature present in their L2 grammar.

In all the three tasks, the participants were unable to understand the ongoing value of the Present Tense in Spanish, allowing it in some cases but judging it unacceptable in 
others. This therefore indicates that at least some of those features have been attrited by the influence of the English setting of the parameters. Cuza concluded that there was no pattern as to which sentences with the ongoing Present Tense in Spanish were judged acceptable or unacceptable. If all the subjects had still been able to use or recognize the Present Tense in Spanish with the ongoing interpretation, the results would then support the claim argued by the Interface Hypothesis. However, because the results show that a purely syntactic feature such as the ongoing value of the Present Tense was affected by the influence of the L2 grammar, the conclusion is that attrition can occur, and in particular that interface-related features are subject to L1 attrition.

2.9 Incomplete Acquisition and L1 Attrition of Subject-Verb Inversion in Spanish: Optionality Outside the Interfaces - Alejandro Cuza

In his paper, "Incomplete Acquisition and L1 Attrition of Subject-Verb Inversion in Spanish: Optionality Outside the Interfaces", Alejandro Cuza addresses the Interface Hypothesis of First Language Attrition introduced above (Sorace, 2005; Tsimpli \& Sorace, 2006). According to this hypothesis, purely syntactic features such as VP syntax will remain unproblematic to L2 interference and therefore not suffer L1 attrition, and Cuza ends up arguing against this theory.

The author defines attrition as "the grammatical restructuring of a previously acquired L1 system due to intense contact with a dominant L2". He provides an example of previous research done by Sorace $(2000 ; 2005)$ to illustrate the idea of attrition:

(32) a. Perchè Giorgio non è venuto alla festa?

Why didn't Paolo come to the party?

b. Perchè lui è troppo timido. (bilingual option) 
Because he is too shy

c. Perchè __è troppo timido. (preferred monolingual option)

Because is too shy

Example (32) shows that monolingual Italian speakers prefer the answer to the question in (32a) as in (32c), without the overt subject, as expected in a pro-drop language. Italian speakers under the influence of English as their L2 prefer option (32b), with the overt subject lui, and this is explained by the influence of the syntax of a nonpro-drop language (English) on a pro-drop language (Italian).

The goal of Cuza's current study is to examine how Spanish Heritage speakers and adult bilinguals react with respect to subject position in matrix and embedded whquestions, and if the results show such feature to be problematic, how to account for that (in terms of age or onset of L2 acquisition). To illustrate the differences between the languages studied (English and Spanish) in terms of sentence structure, Cuza assumes that in Spanish the verb is raised to spec of CP (Comp) both in matrix and embedded whclauses, whereas in English, the auxiliary, not the main verb, moves from head of IP to spec of CP. No movement takes place in embedded wh-clauses in English, as shown by the tree structures below: 


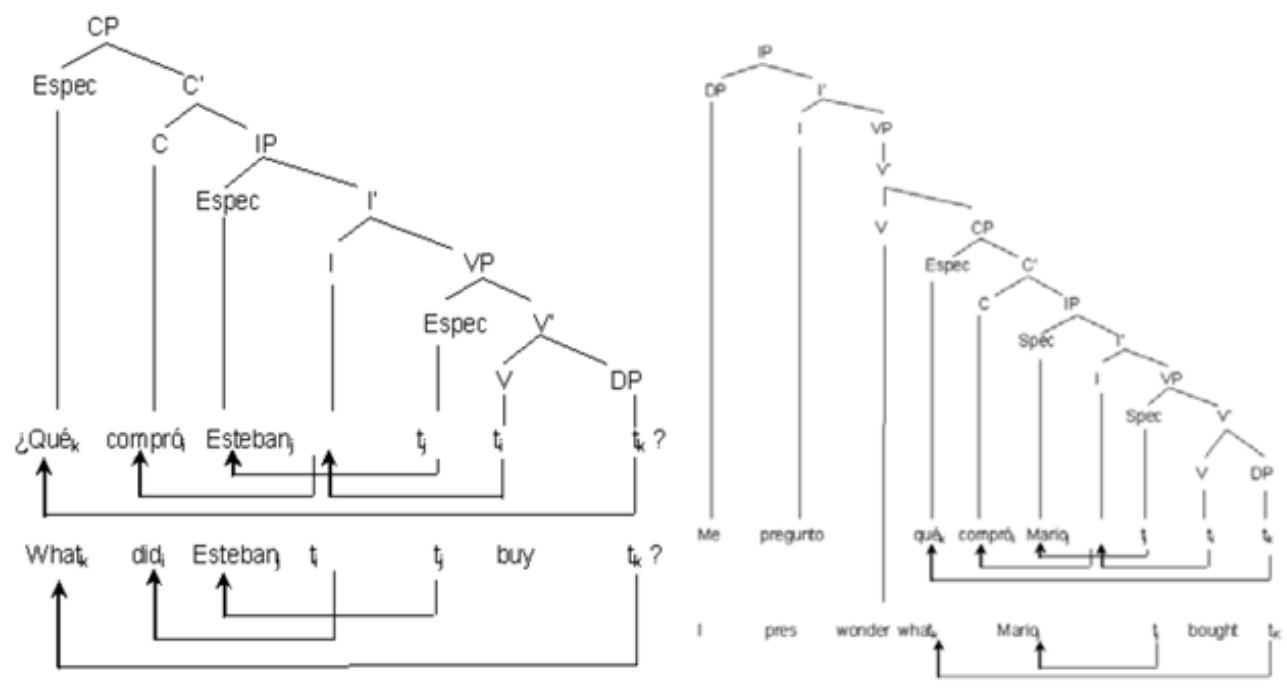

For this study, a total of forty-two subjects were tested. They were divided into three groups (fourteen heritage speakers, sixteen adult immigrants and twelve formed the control group - native Spanish speakers from South America). They were given two tasks. The first one consisted of a grammaticality judgment test, in which they were shown a set of sentences and then asked to judge their acceptability in their dialect, as presented below:

\section{Me pregunto qué Ernesto compró.}

"I wonder what Ernesto bought." -2 (odd) -1 (slightly odd) 0 (I don't know) 1 (more or less fine) 2 (perfectly fine)

The second task was called the "Dehydrated Sentence Task", which had the participants put words together in order to form a grammatical sentence in Spanish, as follows: No sé/ qué / Victor / decir / del/ regalo/ [embedded-ung] 


\section{¿/A quién / Luis/ conocer /Paris/ ? [matrix-ung]}

According to the Interface Hypothesis of First Language Attrition, both bilinguals and heritage speakers are expected to find subject-verb inversion not problematic due to the fact that the contrast between English and Spanish is not one of pragmatic or discourse interfaces, but one of narrow syntax. As stated earlier, this theory suggests that the learning of VP syntax should remain unproblematic, therefore attrition is not expected.

However, after analyzing the results, Cuza did not confirm this hypothesis. In contrast, both groups accepted a good amount of ungrammatical sentences where subjectverb inversion was obligatory. The main conclusion is that the Interface Model of Attrition is not supported; there are external factors involved, such as syntactic complexity of the structures, reduced input of the L1, similarities between L1 and L2, and the educational level of the bilingual speaker.

3. Literature on the Syntax of Pronominal Subjects in Brazilian Portuguese and English

The Null Subject Parameter (NSP) divides languages into pro-drop languages (such as Peninsular Spanish and Romance languages in general) and non-pro-drop (such as English). In this section, I provide an overview of the relevant literature on the Prodrop Parameter in Brazilian Portuguese and English. In typical null subject languages such as Peninsular Spanish, the pronominal subject of a finite clause is typically not expressed overtly, as in (35). 
Peninsular Spanish:

(35) Salí de la casa.

Left-I from the house

'I left the house.'

In these languages, the expression of a pronominal subject of a finite clause is typically interpreted as contrastive or focused, as in (36):

(36) Yo salí de la casa.

I left from the house

'It was I who left the house.'

On the other hand, in typical non-null subject languages such as Modern English, the pronominal subject of a finite clause is expressed overtly, as in (37).

(37) I left the house.

In these languages, the omission of a pronominal subject of a finite clause is unacceptable, as in (38).

(38) *Left the house.

Brazilian Portuguese, as has been noted, seems to behave in a transitional way in the sense that some of its pro-drop properties have been or are being lost, and is therefore referred to as a "restricted null-subject" language. The main claim suggested by this theory is that in main clauses, "first and second referential null subjects are not pro instances of topic-deletion" (Ferreira 2000, Modesto 2000, and Rodrigues 2004).

The empty category in the subject position of constructions such as (39a), for instance, is taken to be a variable bound by a zero topic; thus, the presence of an intervening wh-element between the empty topic and the variable in subject position in 
(39b) yield a minimality effect. Fully Null Subject languages such as Peninsular Spanish or Italian do not show this restriction.

a. Fiz um bolo.

made-1PSG a cake

'I made a cake.' b. ?*O que fiz? what made-1PSG

'What did I make?'

Brazilian Portuguese does not generally allow third person referential null subjects in main clause:
a. *pro estava cansado (Rodrigues, 2004)
b. Ele estava cansado was-3Sg tired He was-3Sg tired 'He was tired.' 'He was tired.'

However, BP licenses null third person referential subjects in embedded finite clauses. This is illustrated in (41).

(41) Pedro disse que pro falava alemão.

Pedro said that pro spoke German

"Pedro said that he spoke German.'

Significantly, embedded clause third person referential empty subjects need to have an antecedent which is the closest c-commanding one in the clause. (Fully Null Subject languages, such as Spanish and European Portuguese, do not exemplify these restrictions on the distribution of embedded subjects.)

(42) Ele disse que [o pai do Pedro $]_{i}$ acha que (ec) $)_{i}$ vai ser promovido

He said that [the father of the Pedro $]_{i}$ thinks that $(\mathrm{ec})_{\mathrm{i}}$ goes be promoted He said that [Pedro's father $]_{\mathrm{i}}$ thinks that he $\mathrm{e}_{\mathrm{i}}$ is going to be promoted' 
(43) Ele j $_{\mathrm{j}}$ disse que o pai do Pedro acha que (ec) * $_{*_{\mathrm{j}}}$ vai ser promovido

$\mathrm{He}_{\mathrm{j}}$ said that the father of the Pedro thinks that $(\mathrm{ec}) *_{\mathrm{j}}$ goes be promoted

$\mathrm{He}_{\mathrm{j}}$ said that Pedro's father thinks that he ${ }_{{ }_{\mathrm{j}}}$ is going to be promoted'

(44) Ele disse que o pai $\mathrm{d}[\mathrm{o} \text { Pedro }]_{\mathrm{k}}$ acha que $(\mathrm{ec})_{*_{\mathrm{k}}}$ vai ser promovido

He said that the father of [the Pedro $]_{\mathrm{k}}$ thinks that $(\mathrm{ec}) *_{\mathrm{k}}$ goes be promoted

He said that $\left[\right.$ Pedro $\left._{\mathrm{k}}\right]$ 's father thinks that he ${ }_{* \mathrm{k}}$ is going to be promoted'

(45) Ele disse que o pai do Pedro acha que (ec) *1 $_{1}$ vai ser promovido

He said that the father of the Pedro thinks that $(\mathrm{ec}) * 1$ goes be promoted

He said that Pedro's father thinks that he $*_{1}$ is going to be promoted'

Sentence (42) carries the natural interpretation that the null subject refers back to the subject of the embedded clause that antecedes it. Sentence (43) is unacceptable as the null subject cannot refer back to the subject of the matrix clause. Sentence (44) is also unacceptable as the null subject does not refer back to Pedro (but to his father, since 'father' is the main part of the subject of the embedded clause). Sentence (45) is unacceptable as the null subject cannot refer to a person other than the subject of the embedded clause that antecedes it.

Note that Modern English does not show a contrast between main and embedded clauses - the pronominal subject of finite clauses must be overtly expressed, whether in the main clause, as indicated by the examples in (46), or in the embedded clause, as indicated by the examples in (47):

(46) a. I made a cake

b. *pro made a cake 
(47) a. He said that Pedro's father thinks that he is going to be promoted.

b. *He said that Pedro's father thinks that pro is going to be promoted.

3.1. The Null Subject Parameter and Parametric Theory - Osvaldo Jaeggli and Kenneth J. Safir

Osvaldo Jaeggli and Kenneth J. Safir present, in the paper "The Null Subject Parameter and Parametric Theory", an overview of parametric theory assuming the Government-Binding (GB) approach. In addition, the authors discuss and analyze some issues triggered by the null subject phenomena, as well as some GB assumptions about null subjects. Furthermore, Jaeggli and Safir present their own theory of the Null Subject Parameter.

The authors claim that "knowledge of grammar is unconscious, systematic and complex, though it appears to arise without explicit instruction". This claim is intrinsically related to the theory that there is a Universal Grammar (UG) as an innate feature of human beings. They also point out that there is remarkable variation in the linguistic knowledge attained by adult native speakers cross-linguistically. Such language variation can be explained by specific parameters which interact with universal principles to generate grammars of different languages. Any phenomenon that is not learned or acquired through experience must belong to UG.

The Standard Parameter Theory (SPT), as presented in Chomsky (1981), suggests that "a child may succeed in language acquisition because it is innately provided not only with a set of universal principles of grammar which are invariant across languages, but also a set of parameters that provide optional grammatical postulates that result in significant linguistic variation". On the basis of this approach, the interaction between 
this set of parameters and the universal principles of grammar (UPGs) results in a particular grammar.

Perlmutter (1971) noted that languages differ with respect to whether they require an overt pronominal subject, as in English, or not, as in (1):

(48) a. John $/ * \varnothing$ saw that film.

b. Juan / Ø vio ese film.

Safir and Jaeggli review the evidence for the existence of an empty category in a sentence such as the Spanish one in (48b), where there is no subject pronounced. The restrictions observed under Binding Theory support the postulation of this category.

According to the Binding Conditions proposed by Chomsky (1981),

(a) An anaphor is bound in its governing category

(b) A pronoun is free in its governing category

(c) A name is free

a. $\mathrm{John}_{\mathrm{i}} / \mathrm{He}_{\mathrm{i}}$ saw himself $/{ }^{*} \mathrm{John}_{\mathrm{k}} / * \operatorname{him}_{\mathrm{j}}$.

b. $\mathrm{John}_{\mathrm{i}} / \mathrm{He}_{\mathrm{i}}$ said Mary saw / *himself / $\mathrm{John}_{\mathrm{k}} / \mathrm{him}_{\mathrm{i}}$.

Examples (49a) and (49b) help us understand with more clarity the Binding Conditions shown above. In (49a), the anaphor "himself" must be coreferent with the NP "John", and the pronoun "him" is not allowed to be coreferent with "John", by Principle B, or the name John, by Principle C. Sentence (49b) shows that the reflexive "himself" cannot occur here by Principle A, since the anaphor must be bound in its governing category, and due to gender constraints it cannot refer back to Mary. The pronoun "him", however, is allowed since it is free in its governing category. 
Governing Category: A is the governing category for B if A is the first maximal projection dominating the governor of $\mathrm{B}$ which also has a subject accessible to $\mathrm{B}$.

The authors suggest that "the gap where a lexical subject might have appeared acts as an antecedent for the Binding Conditions", which justifies the existence of an empty subject, phonetically null but syntactically present. Therefore, a sentence such as (50) has to abide by the Binding Conditions.

(50) a. Juan / él / Ø / siempre habla de si mismo.

b. John / he / Ø / always talks about himself

Both English and Spanish have empty subjects in infinitival contexts, as shown in (51):

(51) a. John was happy to kill himself.

b. Juan intentó __ hablar de si mismo.

However, one of the properties of NSLs is that they may have phonologically null subjects in tensed sentences, which is not the case in Non-NSLs. The empty category subject found in tensed sentences is commonly identified as pro, and the empty subject of infinitives is known as PRO. One of the clear differences between the two categories is that pro is free and specific, whereas PRO adopts a more generic interpretation unless controlled by another Noun Phrase (NP). The authors use the example below to illustrate this claim:

(52) It is impossible PRO to leave.

Sentence (52) shows us that the interpretation is generic, that it is impossible for anyone to leave, not one person in specific, but anyone. But PRO can also have a controlled interpretation which is specific to one determined subject, as shown in (53):

(53) John tried PRO to leave. 
This sentence has a controlled interpretation for PRO, which refers specifically to John, no one else. Another difference is that PRO cannot be a resumptive pronoun, while pro can as shown in (54):

(54) (a) *That's the guy who $_{\mathrm{i}}$ we didn't know whether it was possible PRO to swim.

(b) *Ese es el tipo que $_{\mathrm{i}}$ no sabíamos si sería posible PRO nadar.

(c) That's the guy $\mathrm{who}_{\mathrm{i}}$ we didn't know whether we should talk to him ${ }_{\mathrm{i}}$.

(d) Ese es el tipo que $_{i}$ no sabíamos si sería posible hablar con él $l_{i}$.

Chomsky (1981) also proposed the "Extended Projection Principle" which states: "Every S must have an (NP,S) (i.e., a structural subject)." In some languages such as English, there are certain contexts which allow for the existence of the so-called expletive elements, namely it or there, as shown in (55):

(55) a. It seems that John is sick.

b. There are several solutions.

The presence of such lexical non-thematic elements is required in English, whereas in most NSLs it is common to find an empty subject in that position, as in the counterpart Brazilian Portuguese examples given in (56):

(56) a. Parece que o João está doente.

Seems that the John is sick

b. Há várias soluções.

Exist several solutions

It is important to mention that the fact that a language allows for null expletive subjects does not mean that it also allows for null thematic subjects, while the reverse does seem to be true. Spanish and Brazilian Portuguese, for example, allow for both null 
thematic and expletive subjects, but German, in contrast, allows for null expletive subjects, while still maintaining its Non-Null-Subject characteristics for thematic subjects, as shown below:

(57) a. Él / Ø dijo que Ø mató al perro.

he said that killed the dog

He said that he/she killed the dog.

b. Él / Ø dijo que Ø le parece que Juan mató al perro.

He said that to-him seems that Juan killed the dog

He said that it seems to him that Juan killed the dog.

(58) a. Ele / Ø disse que Ø matou o cachorro.

he said that killed the dog

He said that he killed the dog.

b. Ele / Ø disse que Ø lhe parece que o João matou o cachorro.

He said that to-him seems that the João killed the dog

He said that it seems to him that João killed the dog.

(59) a. *Er sagte, dass __ den Hund getötet hat.

He-NOM said that the-ACC dog killed has

He said that she/he has killed the dog.

b. Er sagte, dass __ ihm scheint, dass Hans den Hund getötet hat.

He-NOM said that him-DAT seemed that Hans the-ACC dog killed has

He said that (it) seemed to him that Hans killed the dog.

Examples (57a) and (58a), from Spanish and Brazilian Portuguese, respectively, show the typical thematic null subjects, not present in the German example in (59a). 
However, (59b) demonstrates how German also has the expletive null subjects as shown in $(57 b)$ and (58b), despite not having thematic null subjects.

One erroneous assumption about Null Subjects is that they are necessarily related to the "richness" of the inflectional system of NSLs. When considering the data from Spanish, in (60),

(60) habl-o - I speak

habl-as - you speak

habl-a - he/she speaks

habl-amos - we speak

habl-ais - you (pl.) speak

habl-an - they speak

one can conclude that each verb ending is distinct from one another, eliminating the need for an overt subject, which is not possible in English as there are only two forms in the Simple Present. This would support the assumption above. However, languages such as Chinese and Japanese have no number-person inflection (which then makes them less "rich" than English), yet they both allow for thematic and expletive subjects to remain phonologically null, as shown in the Japanese examples in (61):

$\begin{array}{llll}\text { yom-ru } & \text { read-present } & \text { yom-oo } & \text { let's read } \\ \text { yom-ta } & \text { read-past } & \text { yom-hai } & \text { want to read } \\ \text { yom-anai } & \text { read-neg } & \text { yom-are } & \text { was read } \\ \text { yom-eba } & \text { read-conditional } & \text { yom-ase } & \text { make read }\end{array}$

A suggestion in the literature, therefore, is that it is not so much the "richness" of inflection that determines whether a language licenses pro in subject position, but is 
perhaps a matter of the uniformity of inflection - either consistently inflected languages (for example, Spanish), or consistently non-inflected languages (for example, Chinese) seem to allow pro.

Jaeggli and Safir conclude that there are several contrasts between the behavior of PRO and pro; pro behaves in the same way that overt pronouns do - it allows a resumptive interpretation, and permits an expletive meaning, while PRO allows neither of these constructions.

3.2. Topics in Language Acquisition - Vivian Cook and Mark Newson (from “Chomsky’s Universal Grammar" - an Introduction)

In chapter eight of the book Chomsky's Universal Grammar - An Introduction, Cook and Newson explore some issues based on Principles and Parameters theory. The authors state that at early stages of language acquisition, English speaking children produce sentences such as $(62)$ :

(62) a) Here book.

b) Slug coming.

One of the main hypotheses as the time of Cook and Newson's writing was the claim that the child's production lacks functional phrases, which, according to the authors, either have lexical heads, such as "the" in "the book" or a grammatical inflection such as the morpheme $-\mathrm{s}$ in "lives". Following this line of reasoning, we conclude that functional categories do not carry meaning; they rather serve a "function" within the sentence. The choice and sequence of words is more useful to the child than the syntax. According to the claim described above, child language only has lexical phrases, or, in 
other words, the meaningful items in the sentence. Sentences (63a) and (63b) are the same sentences (62a) and (62b) with the functional items:

(63) a) Here is the book.

b) The slug is coming.

Since there are no functional phrases, there is no $\mathrm{V}$ movement. In addition, because of the lack of DPs, the sentences produced at this stage have no pronouns, since pronouns are the heads of DPs. Tense and agreement markings are not present; therefore, a sentence such as "Daddy sleep" could mean "Daddy is sleeping" or "Daddy slept" since the child does not make a clear distinction of tense.

Wh-questions and inversion questions are also not available to the child, as verb movement would be required for CPs to take place. Since there are no CPs, there is nowhere for the verb to move to. Negation is one functional category that is inarguably present in the child's speech, which in English, appears as "No" at the beginning of the sentence, yielding constructions such as "No a boy bed". This theory is not supported cross-linguistically, as in the German examples shown below in (64):

(64) a) Kaput is der. (broken is it)

b) Da fährt die Caroline.

(there goes Caroline)

The data above suggest that there is both an AGRP and a TP, and children use the TP as a place where they move the finite verb to. 
It has been suggested by Hyams (1986) that children's early English is in fact a pro-drop language. Cook and Newson state that "children start with a pro-drop setting that allows the empty category pro in subject position", as shown in (65):

(65) a) Make a house.

b) Read bear book.

The authors suggest that English children learn with time that English is a nonpro-drop language, and therefore adjust to its properties. However, as noted by Cook and Newson, there appear to be problems with the analysis. Among these are: Radford (1990), who claimed that null-objects commonly occur in children's speech; Valian (1989), who showed that English speaking children produce fewer null-subject sentences than Italian speaking children, which implies that they must know somehow that English sentences need subjects. Hulk (1987) pointed out that French children do not go through a null-subject stage, and Bloom (1990) argued that the length of the VP was related to the frequency with which the children produced null-subjects. According to this claim, nullsubjects appeared in longer sentences, and overt subjects in shorter sentences to compensate for the sentence length.

If there is no AGRP, children cannot clearly specify who they are referring to as their subject. In the literature on pro-drop, originally, these languages were associated with "rich" inflectional paradigms. In languages such as Spanish and Italian, the "rich" inflectional morphology leaves less doubt as to who the null-subject is, because of gender and number agreement. One very important feature of pro-drop languages is that they are morphologically uniform, as discussed above, as argued by Jaeggli and Safir (1989). Non-pro-drop languages are, on the other hand, morphologically non-uniform. In other 
words, a language is considered morphologically uniform when all the possible inflections have to follow a similar pattern. Spanish and Chinese are both morphologically uniform, as in Spanish all the inflections are complex, and in Chinese, none of them are complex. English, however, is "mixed", as the pattern is not the same for all six inflections, as shown in (66):

(66) English

$1^{\text {st }}$ ps I speak

$2^{\text {nd }}$ ps You speak

$3^{\text {rd }}$ ps He speak-s

$1^{\text {st }}$ ppl We speak

$2^{\text {nd }}$ ppl You speak

$3^{\text {rd }}$ ppl They speak
Spanish

habl-o

habl-as

habl-a

habl-amos

habl-ais

habl-an
Chinese

shuo

shuo

shuo

shuo

shuo

shuo

The Null Subject Parameter suggested by Jaeggli and Safir (1989) is: "Null subjects are permitted in all and only languages with morphologically uniform inflectional paradigms". Such claim also suggests why child language is pro-drop, as there is morphological uniformity. Once the child learns the different morphological patterns, the presence of a pro-form becomes necessary.

Because Brazilian Portuguese, like Spanish, is morphologically uniform, the prediction is that the pattern should be the same. However, new theories such as suggested by Duarte $(1993,1995)$ show that there is an increasing need for an overt proform in certain contexts in Brazilian Portuguese, which characterizes it as a NSL that is losing some of its Null Subject properties. 
According to the model proposed by Wexler and Manzini (1987), $\beta$ is the governing category for $\alpha$ iff $\beta$ is the minimal category which contains $\alpha$ and a governor for $\alpha$ and:

(a) a subject, or

(b) an inflection, or

(c) a tense, or

(d) an indicative tense, or

(e) a root tense

Languages are associated with one of the values of this parameter depending on the syntactic features that they use. English, for example, takes value (a) because any category with a subject can be a governing category.

In order to account for the late development of pronominals, Cook and Newson suggest that at first, children may misanalyze pronominals as anaphors, and for that reason give them too-close antecedents. Children are also unable to attribute a pronominal to a verb inflection, given that these are unavailable to them.

3.3. The Null Subject Parameter and the Classical Analysis of pro - Julio VillaGarcía

In Chapter 2 of his M.A. dissertation, Julio Villa-García presents a clear analysis of subject drop, from a generative perspective. Villa-García states that Universal Grammar (UG) “comprises a set of principles", which are general to human language. These principles are then combined with a number of settings or values known as parameters in order to allow for variation across languages. 
The Extended Projection Principle (EPP) proposed by Chomsky (1981a) suggests that sentences and clauses alike are all required to have a subject, whether overt or null. Chomsky also points out that there are certain properties which co-occur in typical NSLs, as shown in (67):

(67) a) missing subject

b) free inversion in simple sentences

c) "long wh-movement" of subject

d) empty resumptive pronouns in embedded clause

e) apparent violations of the *[that-t(race)] filter

In order to illustrate these properties, Chomsky (1981) gives the examples shown in (68):

(68) a) missing subject

ho trovato il libro

found the book

("I found the book")

b) free inversion in simple sentences

ha mangiato Giovanni

ate Giovanni

(“Giovanni ate")

c) "long wh-movement" of subject

l'uomo [che mi domando [chi abbia visto]]

(with the interpretation: "the man $x$ such that I wonder who $x$ saw")

d) empty resumptive pronouns in embedded clause

ecco la ragazza [che mi domando [chi crede [che possa VP]]] 
(she) is the girl that (I) wonder who thinks that (she) may VP

("this is the girl who I wonder who thinks that she may VP")

e) apparent violations of the *[that-t(race)] filter

chi credi [che partirà]

who (you) think that will leave

("who do you think [(that) will leave]")

Chomsky argues that properties (a) and (b) are exclusively present in NSLs, whereas properties (c), (d) and (e) can appear in non-pro-drop languages such as English.

The Overt Pronoun Constraint (OPC) suggests that an overt pronominal must not have a quantified antecedent in languages that allow an overt/null alternation. In Spanish, for example, "a visible pronoun cannot refer back to a quantified antecedent".

(69) $[\text { Todos }]_{\mathrm{i}}$ piensan que ellos $*_{\mathrm{ij}} /(\text { empty category })_{\mathrm{ij}}$ son inteligentes

("They all $_{\mathrm{i}}$ think that they $\mathrm{y}_{\mathrm{i} j}$ are intelligent")

Sentence (70) below illustrates a difference between PRO and pro:

(70) a. pro Quiero PRO ir a Brasil.

b. I want PRO to go to Brazil.

In the Spanish sentence (70a), pro does not refer back to anything within that sentence, whereas PRO refers back to the subject (pro), which is being used in place of the $1^{\text {st }}$ person pronoun "Yo". Therefore, pro, unlike PRO, is not an anaphor, but they are both pronominal in the sense that they are used in place of nouns. PRO occurs in both Null-Subject and Non-Null-Subject Languages, generally in non-finite clauses, whereas pro is the silent subject of finite clauses in Non-Null Subject Languages. 
3.4. Null Subjects in European and Brazilian Portuguese - Pilar Barbosa, Maria Eugenia Duarte and Mary Kato

In the paper "Null Subjects in European and Brazilian Portuguese", Barbosa, Duarte and Kato briefly discuss the "Avoid Pronoun Principle" proposed by Chomsky (1981) and provide a comparison between the distribution of the third person pronouns in European Portuguese (EP) and Brazilian Portuguese (BP). The goal of the paper is to show how BP is losing the properties associated with the Null Subject Parameter.

The authors state that typical NSLs follow the pattern described below:

a. phonologically null subjects;

b. SV, VS order alternations (so-called "free-inversion");

c. lack of that-trace effects: extraction is from post-verbal position.

To illustrate these properties and show how they contrast from typical Non-NSLs such as English, they give the following examples from EP:

(71) a. Telefonaram.

'They called.'

b. *Called.

(72) a. Telefonou o Joāo.

b. *Called John.

c. O Joāo telefonou.

'John called.'

(73) a. *Which student did you say that bought a computer?

b. Que aluno disseste que comprou um computador? 
Another difference pointed out by the authors is that in NSLs, pronouns in embedded clauses generally do not refer back to the matrix subject, as in (74):

(74) a. O Joāo disse que ele comprou um computador.

b. O Joāo disse que comprou um computador.

c. $\mathrm{John}_{\mathrm{i}}$ said that he $\mathrm{i}_{\mathrm{k} k}$ bought a computer.

In (74a), the most natural reading is the one in which a person other than John bought a computer. The anaphoric reading is provided in (74b), with a null subject in the embedded clause. Since English is a Non-NSL, the pronoun "he" is necessary, therefore both readings can be obtained from (74c). The "Avoid Pronoun Principle" suggests that speakers of NSLs will introduce a pronoun as a topic only when "it is required to signal topic switch or for emphasis/empathy" (cf. De Oliveira 2000).

Duarte $(1993,1995)$ argued that BP speakers increasingly use overt pronominal subjects, when a null subject would be required in EP. BP speakers also tend to double the subject with an overt pronoun, as shown below in (75):

(75) a. [A Clarinha $]_{i}$ ela ${ }_{i}$ cozinha que é uma maravilha. the Clarinha she cooks that is a wonder 'Clarinha, she cooks wonderfully.'

Such event of subject doubling is only possible in EP as epenthetic, or when the speaker is hesitating, as mentioned by Barbosa, Duarte and Kato. Their comparative analysis concluded that in EP, overt subject pronouns are most likely [+animate], whereas in BP they can be equally [+animate] or [-animate], as shown in (76):

(76) a. $[\text { A casa }]_{\mathrm{i}}$ virou um filme quando ela $\mathrm{a}_{\mathrm{i}}$ teve de ir abaixo. BP the house turned-into a movie when it had to go down 
'The house became a movie when it was demolished.'

b. [A casa]i virou um filme quando Øi teve de ir abaixo. EP the house turned-into a movie when $\varnothing$ had to go down

'The house became a movie when it was demolished.'

According to Duarte (1993), the decrease of null subjects in BP had influence on the first and second persons more than the third. Such behavior is unexpected, since second and third person singular are morphologically unmarked in Portuguese, as shown in the paradigm below:

Eu fal-o

Tu fal-as

Ele/Ela fal-a

\section{I speak}

You speak

He/She speaks

However, several dialects in BP use both the forms "tu" and "você" for second person, which also happens in EP. The difference is that these dialects of BP use the third person form of the verb for both "tu" and "você", which is unacceptable in EP, as shown in (77):

(77) a. Tu falas/*fala espanhol (EP). Tu fala/falas espanhol (BP).

'You speak Spanish'

b. Você fala espanhol (both EP and BP).

'You speak Spanish'

Since there is a distinction in behavior, some Brazilian linguists argue that the third person null subject must be a different type of empty category. Figueiredo Silva (1996), Negrāo \& Müller (1996) and Modesto (2000) consider it a variable, whereas Ferreira (2000) and Rodrigues (2004) argue that it is a trace of A-movement. 
3.5. Two Italian Dialects and the Null Subject Parameter - Luciana Brandi and Patrizia Cordin

Luciana Brandi and Patrizia Cordin present, in their article, an analysis of two Italian dialects (Trentino and Fiorentino) and how they behave with respect to the Null Subject Parameter. The authors argue that although both dialects should be considered NSLs, they require a phonetic realization of subject clitics, as in French. The scheme below shows that Fiorentino and Trentino are similar to French in the sense that they require in almost all environments a phonetic realization of subject clitics:

(F)

(E) parlo

Tu parli

E parla

La parla

Si parla

Vu parlate

E parlano

Le parlano
Parlo

Te parli

El parla

La parla

Parlem

Parlé

I parla

Le parla
French

Je parle

Tu parles

Il parle

Elle parle

Nous parlons

Vous parlez

Ils parlent

Elles parlent
I speak

You speak

He speaks

She speaks

We speak

You speak (pl.)

They (masc.) speak

They (fem.) speak

Standard Italian is a clear example of a NSL, where omission of the subject clitics is completely acceptable.

(Io) parlo

(Tu) parli

(Lui) parla

(Lei) parla
I speak

You speak

He speaks

She speaks 
(Noi) parliamo We speak

(Voi) parlate You speak (pl.)

(Loro) parlano They speak

As seen above, Florentino only allows an optional subject for the $1^{\text {st }}$ person of the verb, and Trentino requires a subject for $2^{\text {nd }}$ person singular and $3^{\text {rd }}$ person singular and plural. Another difference between these dialects and French is that both Florentino and Trentino allow for the occurrence of a double subject, namely the cooccurrence of a lexical subject and subject clitics, whereas French does not.

(78) a. Mario e parla. (F)

b. El Mario el parla. (T)

Mario speaks

(79) a. Jean parle.

b. Il parle.

c. *Jean il parle.

d. Jean, il parle. (in which case, Jean is a left dislocated subject (LD)

Trentino and Florentino also follow the pattern typical of Null Subject Languages when it comes to free-inversion, whereas Non-NSLs such as English and French do not typically allow this type of construction. Such contrast is shown in (80):

(80) a. Hanno telefonato delle ragazze. (Standard Italian)

b. *There telephoned some girls.

c. *Il a telephoné des filles.

Italian behaves the same way as Trentino and Fiorentino when it comes to subject free inversion, as shown in (81): 
(81) a. Gl'ha telefonato delle ragazze. (F)

b. Ha telefoná qualche putela. (T)

There telephoned some girls.

On the basis of the discussion above, the authors concluded that both Trentino and Fiorentino should be considered NSLs, as they differ from French in two main points: (1) the subject clitic in both dialects can also be present in sentences where the subject position is lexically filled, and (2) free subject inversion is allowed in Trentino and Fiorentino.

3.6. The Null Subject Parameter in Language Acquisition - Nina Hyams

The paper "The Null Subject Parameter in Language Acquisition", by Nina Hyams, presents an investigation of the relationship between the parameters of Universal Grammar (UG) and real-time grammatical development. The parameter in question is the Null Subject Parameter, which explains why languages such as Italian and Spanish allow phonologically null-subjects in tensed sentences.

Zagona (1982) claims that there is a second property that distinguishes NSLs from Non-NSLs, which concerns auxiliary systems. English is a language that allows tagformation, negative placement, VP deletion and Subejct-AUX inversion, as shown in the examples below:

(82) Peter hasn't eaten, has he?

(83) John will not finish this paper.

(84) Mary isn't coming tonight, but Sue is.

(85) Will Robert find his sunglasses? 
Modal verbs in English are also distinct from Italian (or Spanish) modal verbs in the sense that in the latter, they have the same morphological behavior as main verbs. They exhibit a full range of inflection for person, number and tense, unlike English modals.

$\begin{array}{lll}\text { Italian } & & \text { English } \\ \text { Io } & \text { posso } & \text { I } \\ \mathrm{Tu} & \text { puoi } & \text { You/She } \\ \text { Lui, Lei } & \text { può } & \text { We } \\ \text { Noi } & \text { possiamo } & \text { You (pl.) } \\ \text { Voi } & \text { potete } & \text { They }\end{array}$

Hyams claims that the early stages in first language acquisition show a pattern of the so-called "subjectless sentences". Children produce sentences with a phonologically null subject, but it is important to note that these sentences co-exist with their overt subject counterparts, as shown in (86):

(86) a. Change pants.

Papa change pants.

b. Build house

Cathy build house.

The author claims that since the child can produce the same sentence, with or without an overt subject, the choice for its absence is not due to a performance limitation on sentence length. An important similarity between child language and adult NSLs is that the lexical subject is entirely optional, and that a context can provide a referent to that null subject, as shown in (87):

(87) (Eric has just eaten) 
Mother: You ate the apple all up. There's no more apple.

(Eric starts to cry and hits his toys)

Eric: Want more apple.

The context allows for the inference that the subject of the verb "want" must be Eric. Hyams also points out that children process modals and auxiliary verbs after the acquisition of main verbs. The acquisition of modals and auxiliary verbs does not follow the same pattern cross-linguistically. In Italian, for example, the modals potere (can) and devere (must) can also be identified and analyzed as main verbs, and as a result, will be acquired earlier than the English modals, since English children do not analyze modals as verbs.

Semi-auxiliaries such as hafta and gonna are acquired at an earlier stage, before the so-called "real modals", as suggested by Bellugi (1967). Since they are semantically equivalent to must and will, a semantic account does not explain why there is an earlier stage in the acquisition process. The reason given in this paper is that hafta and gonna are morphologically distinct from their modal counterparts in the sense that there is inflection. In addition, have and go can be analyzed and identified as main verbs, so naturally, children can acquire such forms at the stage when main verbs are being acquired.

Following the line of reasoning above, the auxiliary be should also be analyzed as a main verb, therefore acquired prior to other auxiliaries. Examples (88) and (89) show why this is only partially confirmed:

(88) Adam home.

(89) Here it is. 
In (88), the verb be is omitted, but in (89) the same does not happen. According to Brown (1973), children fail to omit be when a contraction is not possible (*Here it's.), which explains the asymmetry in the pattern for this specific auxiliary in comparison to other modals and semi-auxiliaries. Children only start including this so-called 'contractible' be in their production at the stage when modals are being produced.

Hyams attempts to provide an explanation of certain aspects of language acquisition within the parameterized theory of grammar (Chomsky 1981), in the light of the Null Subject Parameter. She intends to provide an account of different acquisition phenomena which are apparently unrelated and at the same time, show how these phenomena relate to the general process of grammatical development. 


\section{III - METHODOLOGY}

This chapter reports and discusses the procedures involved in two experiments; (1) an elicited production task, and (2) a grammaticality judgment task. More precisely these tasks target null subject behavior in matrix and embedded clauses. As discussed in Chapter 2, Brazilian Portuguese is described in the literature as a language in transition from Null-Subject to Non-Null Subject, maintaining some NSL features but behaving much like a Non-NSL in some contexts. The purpose of the two tasks is to investigate whether proficiency in the L2 (English) has any effect on the production and judgment of L1 (Brazilian Portuguese) sentences. The second aim of the experiment is to analyze the results in the light of the Interface Hypothesis proposed by Tsimpli and Sorace (2006). The Interface Hypothesis suggests that only interpretable features are vulnerable to language attrition. If no significant attrition is detected in regard to Null Subject behavior, the Interface Hypothesis will be confirmed by this experiment; however, if syntactic features are, in fact, attrited, the results of this experiment will then reject this hypothesis.

As discussed in Chapter 2, age, emigration length, education level and amount of contact with one's L1 play a determining role in the attrition process. If an adult decides to move from his/her home country to a place where he/she has little to no contact with his/her native language, it is expected that, after living there for a few years and acquiring near native proficiency in the target language, their L1 will show some signs of attrition. The Interface Hypothesis, formulated on the basis of assumptions with respect to syntactic modularity, suggests that "the changes in L1 syntax will be restricted to the interface with the conceptual /intentional cognitive systems" (Tsimpli, Sorace, Heycock, Filiaci 2004). The hypothesis claims that this attrition phenomenon only affects 
interpretable features, that is, words and expressions at the semantic level. Therefore, word-retrieval and vocabulary usage are expected to be compromised. However, uninterpretable features such as the behavior of words and expressions at the syntactic level should remain unaltered according to this theory. This issue is investigated in further detail in this experiment, through a comparative data analysis in order to determine whether the Interface Hypothesis is, in fact, confirmed in regard to Null Subject behavior.

To be precise, given the contrast in the syntax of referential third person pronominal subjects between BP and English, it is predicted by the Interface Hypothesis that there should not be a change in the L1 syntax of third person referential null subjects of embedded finite clause in BP under the influence of L2 English, since the contrast between the two languages with respect to this property is one of narrow syntax, and not of discourse/pragmatics or semantics.

The following sections of this chapter describe the methodological approach used in order to achieve accurate results. Section 3.5 reports on the experimental results and statistical analysis.

1. Data collection procedures

\subsection{Participants}

Participants for the current study are divided into two groups: (1) seventeen monolingual Brazilian Portuguese speakers and (2) seventeen bilingual Brazilian Portuguese and English speakers. Participants in the first group were recruited in and near the cities of Fortaleza and São Luís, in the northeast of Brazil. They were mostly college students, who received extra credit for participating in the experiments. The second group 
of participants consists of bilinguals living in Miami-Dade and Broward Counties, some of which were also given extra credit for participating, since no monetary compensation was offered. All other participants volunteered to participate. Table 3.1 shows background information for each of the thirty-four participants (mean age: 29.2).

Subgroup Age Gender Place of Birth $\begin{gathered}\text { Length of } \\ \text { time in USA }\end{gathered}$

\begin{tabular}{|c|c|c|c|c|c|}
\hline AV & Monolingual & 30 & $\mathrm{~F}$ & Ceará & - \\
\hline BC & Monolingual & 28 & $M$ & Ceará & - \\
\hline BS & Monolingual & 21 & $\mathrm{~F}$ & Ceará & - \\
\hline EC & Monolingual & 20 & $\mathrm{~F}$ & Ceará & - \\
\hline EL & Monolingual & 23 & $\mathrm{~F}$ & Ceará & - \\
\hline FA & Monolingual & 31 & $\mathrm{M}$ & Ceará & - \\
\hline HP & Monolingual & 29 & $M$ & Piauí & - \\
\hline JS & Monolingual & 23 & $\mathrm{~F}$ & Ceará & - \\
\hline LM & Monolingual & 26 & $\mathrm{~F}$ & Roraima & - \\
\hline MA & Monolingual & 33 & $M$ & Ceará & - \\
\hline $\mathrm{MC}$ & Monolingual & 21 & $M$ & Maranhão & - \\
\hline MF & Monolingual & 22 & $\mathrm{~F}$ & Ceará & - \\
\hline MS & Monolingual & 27 & $\mathrm{~F}$ & Ceará & - \\
\hline $\mathrm{RC}$ & Monolingual & 25 & $M$ & Maranhão & - \\
\hline RM & Monolingual & 26 & $\mathrm{~F}$ & Ceará & - \\
\hline SC & Monolingual & 26 & $\mathrm{~F}$ & Ceará & - \\
\hline SN & Monolingual & 24 & $\mathrm{~F}$ & Ceará & - \\
\hline$A F$ & Bilingual & 29 & $M$ & Rio de Janeiro & $10 \mathrm{yrs}$ \\
\hline AG & Bilingual & 43 & $\mathrm{~F}$ & Rio de Janeiro & $16 \mathrm{yrs}$ \\
\hline AS & Bilingual & 23 & $\mathrm{~F}$ & Minas Gerais & 8 yrs \\
\hline $\mathrm{CF}$ & Bilingual & 23 & $\mathrm{~F}$ & Rio de Janeiro & 7 yrs \\
\hline $\mathrm{Cl}$ & Bilingual & 23 & $\mathrm{~F}$ & São Paulo & $8 \mathrm{yrs}$ \\
\hline ER & Bilingual & 48 & $\mathrm{~F}$ & São Paulo & 23 yrs \\
\hline $\mathrm{FB}$ & Bilingual & 33 & $\mathrm{~F}$ & Santa Catarina & 8 yrs \\
\hline FFF & Bilingual & 30 & $\mathrm{~F}$ & Rio de Janeiro & $10 \mathrm{yrs}$ \\
\hline FFM & Bilingual & 37 & $M$ & Minas Gerais & $13 \mathrm{yrs}$ \\
\hline FP & Bilingual & 23 & $M$ & São Paulo & $7 \mathrm{yrs}$ \\
\hline LK & Bilingual & 49 & $\mathrm{~F}$ & Rio de Janeiro & 26 yrs \\
\hline RS & Bilingual & 33 & $\mathrm{~F}$ & São Paulo & $10 \mathrm{yrs}$ \\
\hline SD & Bilingual & 41 & $\mathrm{~F}$ & São Paulo & $11 y r s$ \\
\hline SK & Bilingual & 36 & $\mathrm{~F}$ & Santa Catarina & $10 \mathrm{yrs}$ \\
\hline SL & Bilingual & 22 & $\mathrm{~F}$ & São Paulo & 7 yrs \\
\hline VM & Bilingual & 29 & $\mathrm{~F}$ & Rio de Janeiro & $13 \mathrm{yrs}$ \\
\hline VN & Bilingual & 36 & $\mathrm{~F}$ & Bahia & 10 yrs \\
\hline
\end{tabular}

Table 3.1 - Participants' background information 
All participants have at least some college education. A linguistic background questionnaire was administered prior to the experiment in order to confirm whether or not they met the requirements for participation. The questionnaire includes questions about age, foreign language proficiency, educational level, as well as questions regarding family member's linguistic background (see Appendix).

Although the majority of monolinguals come from the Northeast of Brazil, and the bilinguals are, for the most part, from the Southeast, it is important to point out that dialectal differences shall not interfere in the results of this study, since the two dialects do not differ with respect to this syntactic feature. This matter will be discussed in more detail in the next chapter.

Twenty-three monolingual BP speakers were recruited in Brazil. Of these, six subjects were excluded due to technical problems during the experiment. It is important to note that the term 'monolingual' used here applies to native speakers of BP who have little or no knowledge of a foreign language. A total of twenty-five bilinguals were recruited in the Miami-Fort Lauderdale area, of which eight were excluded due to technical problems. All of the participants had normal or corrected vision as well as normal hearing. No compensation was offered for their participation.

\subsection{Items}

Experimental items consist of fifty sentences in the grammaticality judgment task, among which twenty-four are fillers. All of the items are complete sentences with a subject and one or more verbs. For the elicited production task, a comic strip was used as the basis for elicitation of the participants' natural speech. "Monica's Gang" (originally titled in Portuguese "Turma da Mônica") is the most famous comic book series designed 
for all audiences made in Brazil, and for that reason it was chosen since all subjects were familiar with the characters of the story.

1.3. Tasks

\subsubsection{Elicited production task}

Participants were asked to browse over a comic strip without the speech bubbles in order to avoid priming effects. They were given as much time as needed to make sure they understood the sequence of actions. After that, participants were asked to tell the story in their own words. Their version of the narrative was recorded as they spoke. Participants took an average of 2-3 minutes to tell the story with its important details.

\subsubsection{Grammaticality judgment task}

The grammaticality judgment task consists of a set of fifty sentences (among which twenty-four are fillers). The participants were asked to read each sentence out loud and then, according to their judgment of the acceptability of the sentence, choose one of five options (completely impossible, sounds strange, possible, completely acceptable, don't know) before moving onto the next sentence, while their responses were being recorded. If they judged a sentence as "completely impossible" or "sounds strange", which fall into the unacceptable category, they were asked to provide an acceptable version of the sentence. The reason for this was to identify what strategies participants were using to determine whether or not the sentence was acceptable. In addition, the acceptable versions given by the participants may raise interesting questions, which I will discuss in more detail in Chapter IV. Sentence (90) is a sample sentence from this task:

(90) *Ela disse que o pai do Pedro acha que é alta.

Completamente impossível - Soa estranho - É possível - Completamente aceitável - Não sei dizer 
She said that the father of Pedro thinks that Ø is tall (fem.).

Completely impossible - sounds strange - is possible - completely acceptable - do not know

\subsection{Apparatus and procedure}

The grammaticality judgment task was presented using a small netbook (10.5', ) in a PowerPoint presentation format. The same netbook, which has a built-in microphone, was used to record the auditory stimuli in both tasks. The software used to record the participants' voices was PRAAT (Boersma \& Weenik 2011), a program designed by the University of Amsterdam commonly used for phonetics and speech analysis (Fig. 1).

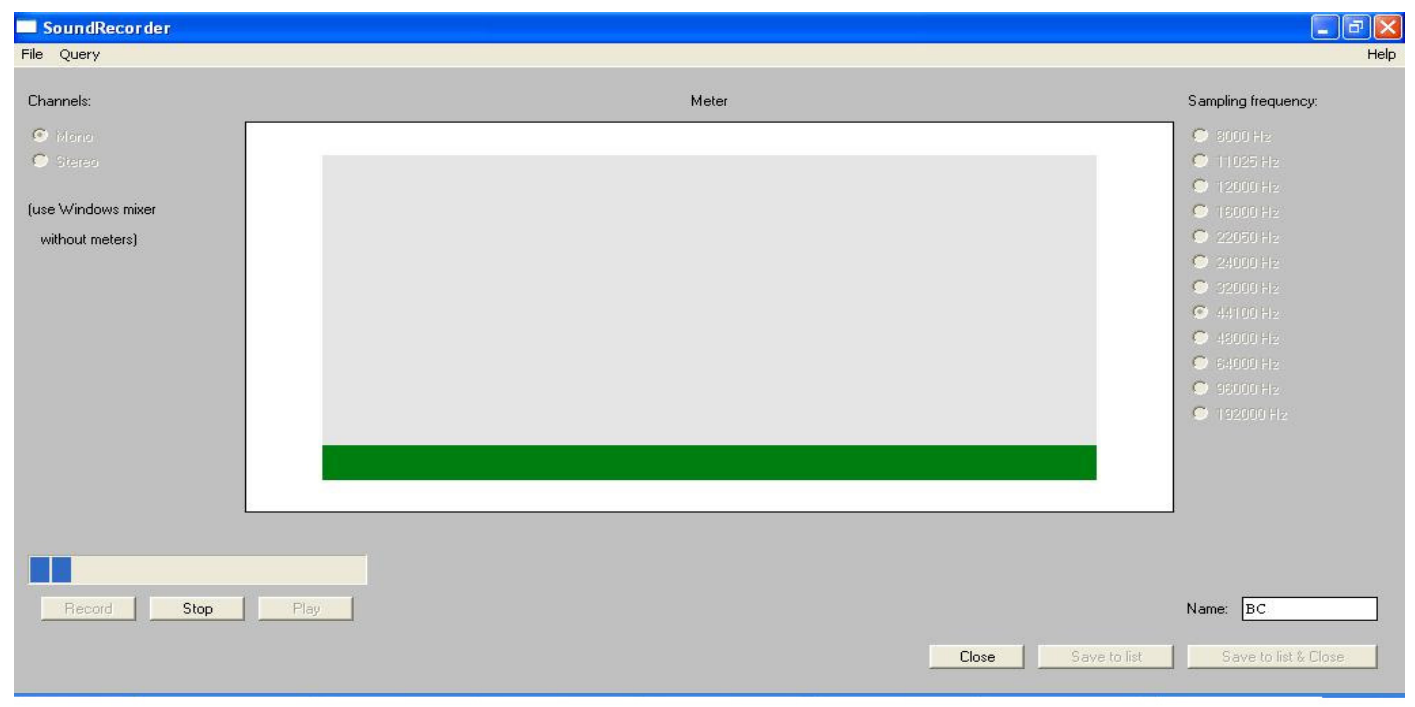

(Fig. 1 - BC's elicited production)

Figure 1 is a screenshot taken during the recording of a participant's (BC) elicited production. The bars on the bottom left side of the screen represent the time, so the participants were told they could speak until the bars reached the far right (approximately four minutes). That does not mean, however, that they had to speak for four minutes. They were free to speak as much as they wanted, but only up to four minutes of their 
speech would be analyzed. The large bar in the center of the screen is a volume bar, which goes up or down according to how loud their voices are perceived by the software.

During the elicited production task, participants were asked to retell the story they had looked over as if they were telling it to a friend, making it as informal as possible and not worrying about grammatical mistakes. Their speech was recorded using PRAAT. Once finished with the story, the recording was stopped and we engaged in informal conversation before starting the grammaticality judgment task.

For this second task, the participants were instructed to be comfortable judging the sentences according to how the language is spoken, again not focusing on grammar errors. It was necessary to point out that they were not being evaluated on the basis of their grammatical knowledge. Once ready, they were shown the first slide and instructed to read it out loud and choose one of the options on the bottom according to their judgment of the sentence. If the sentence was judged "completely impossible", or "sounds strange", they were asked to provide the acceptable version of the sentence. If any of the other three options were chosen, they moved on to the following slide, and the process would start again until the final slide.

\section{Statistical analysis}

In this section, I provide an overview of the data analysis, which will be explored in more detail in the following chapter. In order to analyze the elicited production task, it was necessary to transcribe the voice recordings into text. As shown above, some of the participants took longer than others to tell the story, yielding then fewer subject occurrences as they produced fewer sentences. After transcribing each participant's voice 
recordings, I counted the number of subjects produced by each participant, then divided those subjects into Non-Pronominal, Expletive, Null Pronominal and Overt Pronominal, as shown in the following examples:

Non-Pronominal: "E aí o Cascão aparece pra tentar ajudar..." And then Cascão shows up to try and help... (FA)

Expletive: "Tinha uma poça de lama no meio do caminho." There was a puddle of mud in the way. (EC)

Null Pronominal: "Fizeram cócegas no pé da Mônica...” (they) tickled Monica's foot... (SK)

Overt Pronominal: "Eles cavaram um buraco e encheram de água" They dug a hole and filled (it) with water (VM)

This division was crucial in identifying the difference in pattern between the monolingual production and the bilingual production.

The grammaticality judgment data analysis was performed using the SPSS (Statistical Package for the Social Sciences) software for statistical and logical analysis. Out of the fifty sentences in the task, the twenty-four fillers were removed, and the twenty-six remaining sentences were converted into numbers (s1, s2, etc). The answers given by each participant were also converted into numbers, according to the following scale:

1 - completely impossible

2 - sounds strange

3 - is possible
4 - completely acceptable

5 -don't know 
Crosstabs were created with the numbers, and the statistical tests Fisher's Exact Test and Pearson Chi-Square were applied in order to determine whether there were significant differences between monolinguals and bilinguals in terms of their grammaticality judgment, which will be discussed in more detail in the following chapter.

3. Limitations of this study

No major problems arose during the test sessions. Most of the monolinguals in Brazil were tested in an unusually warm room with a ceiling fan that can be heard in the recordings, making some of their speech indistinct. However, it is unlikely that this interference would affect the results, since there were no questions that arose from this factor with respect to the production of null subjects.

Another issue in the second half of the research process was the fact that Brazilian law does not allow researchers to offer any monetary compensation for participating in a research study. For that reason, I chose not to offer compensation to participants in the US, since I wanted to make sure all participants received the same treatment. This made it slightly harder to find bilingual volunteers. 


\section{IV - RESULTS}

An analysis of research data gathered during both tasks in this experiment is presented in this chapter, and the research questions posed in Chapter I are reiterated and addressed. I will discuss the results of both tasks and how they relate to the hypothesis introduced previously.

\section{Elicited production task}

In order to analyze the data collected during the elicited production task, it was necessary to transcribe each participant's speech. Audio transcription is fundamental to determine the total number of subjects uttered, and out of these, which ones are relevant for our analysis. It is important to mention that a certain participant may have taken longer than another to finish his/her story, which then would most likely imply a higher number of subjects. To avoid complications this difference may cause, exact numbers and percentages are provided in order to yield a more accurate analysis.

Table 4.1 shows the total number of subjects produced by each group, divided into four categories to facilitate the analysis. Non-Pronominal Subjects were separated into a different group in order to help narrow down the set to Pronominal Subjects and Expletive Subjects, which are of more significance for the purposes of this study. The numbers below reflect both matrix and embedded subjects.

It is important to note that coordinated clauses with the same subject are not counted as null occurrences, as NNSLs can also have such constructions such as in the English example below:

(91) John woke up, brushed his teeth, put on his best tie and went to work. 
Sentence (91) does not show any null subject occurrence, since John is the matrix subject of all four coordinated clauses. Constructions such as (91) were not considered for the purpose of this analysis, since no null subject occurrences are present.

\begin{tabular}{|c|c|c|}
\hline & MONOLINGUALS & BILINGUALS \\
\hline Non-Pronominal Subjects & 146 & 196 \\
\hline Expletive Subjects & 11 & 17 \\
\hline Pronominal Subjects (Null) & 78 & 40 \\
\hline Pronominal Subjects (Overt) & 286 & 299 \\
\hline TOTAL NUMBER OF SUBJECTS & 521 & 552 \\
\hline
\end{tabular}

Table 4.1

As shown in table 4.1., the total number of subjects used by the seventeen bilinguals was slightly higher than the total number of subjects produced by the monolingual group. Such discrepancy could have been caused due to slight differences in the length of time each participant took, but it is of no consequence for the data analysis, since the input to analysis is percentages.

Out of the total produced by each group, first examined were the Non-Pronominal Subjects, i.e., DPs such as "Monica", "the dog" or "the puddle", for example. These constitute $28 \%$ of the occurrences in the monolingual group, and $35.5 \%$ among the bilingual subject utterances. Such difference is one not of relevance for the purposes of this study, yet it yields more solid numbers for the other subject occurrences that I will more closely investigate. Expletive occurrences are low in both groups: $2 \%$ among the monolinguals and $3 \%$ among the bilinguals. It is worth mentioning that all expletive occurrences were strictly null, as shown in the example below, from participant FFM: 
(92) “A Mônica tava passeando e viu o Cebolinha comendo um pirulito, mas Ø tinha uma poça de lama no meio do caminho."

"Mônica was strolling by and saw Cebolinha eating a lollipop, but there was a mud puddle in the way."

English expletives are overt, as shown in (93):

(93) "It was hot yesterday."

"There is a puddle over there."

Brazilian Portuguese expletives, however, are covert. Sentence such as (93) and (94) are ungrammatical in BP:

(94) *Ali tinha uma poça de lama no meio do caminho.

"There was a mud puddle in the way."

(95) *Ele chove.

"It rains."

The "There + be" construction in English cannot be literally translated in BP as "There" + "be" or "There" + "have". Brazilian Portuguese uses only the verb "haver" or "ter" (informally) to denote existence. Therefore, sentence (94) is ungrammatical. Any influence of English grammatical structure in this type of construction could be used to debate the Interface Hypothesis, as syntactic attrition would be shown. However, that is not the case with respect to expletives in BP, as they seem to remain unattrited by the influence of L2 English.

After separating out Expletives and Non-Pronominal Subjects, we are left with 364 Pronominal Subjects produced by the monolingual group, and 339 produced by the bilinguals. Out of these, $78.6 \%$ were overt and $21.4 \%$ null among the monolinguals, 
which reinforces the claim suggested by Duarte (1996), that BP's status as a Null Subject Language is in transition. A parallel study conducted in the summer of 2011 in Portugal with native speakers of European Portuguese confirmed that these numbers are much closer in EP, showing a stronger preference for null subjects than in BP. Excerpts from this study on EP are briefly discussed in Chapter 5. The bilinguals produced $88.2 \%$ overt subjects and only $11.8 \%$ null subjects.

It is also interesting to point out that some monolinguals had very few null subject occurrences, which also reinforces the claim suggested by Duarte (1996) that BP is a language in transition from NSL to NNSL. The participant EC, for example, only had one null subject occurrence in her speech (3min24s). The occurrence is shown in (96):

(96) "E aí por baixo fazem cócegas nos pés dela que aí ela finalmente consegue sair de vez..."

"And then from below (pro) tickle her feet so that she is finally able to get out"

In (96), the pro occurrence refers back to Cebolinha and Cascāo, two other characters in the story. The participant could have used the third person plural overt pronoun "eles", which is the equivalent to "they", but did not in this specific instance. Since this participant is twenty years old, the youngest in the control group, one can hypothesize that age may play a role in the transition process, as suggested by Duarte (1996). It seems to be the case that younger monolinguals tend to use more overt subjects, whereas older speakers tend to preserve null subject occurrences. Such a claim has been discussed in the literature confirming a gradual increase in the usage of overt subjects in BP diachronically. According to Duarte (1993), in the first half of the $19^{\text {th }}$ 
century, the rate of overt pronominal subjects was $20 \%$, and this rate rose to $74 \%$ by the end of the $20^{\text {th }}$ century. This, however, is not a direct conclusion drawn from this study, but should certainly be investigated in future research.

In order to confirm these percentages, a repeated measures ANOVA was applied to investigate more closely the differences between both groups. The repeated measures ANOVA on the percentages of each subject category produced resulted in a Subject by group interaction, $\mathrm{F}(3,96)=9.05, \mathrm{p}<.001$. Post hoc tests of within-subject effects indicated significant differences between monolinguals and bilinguals on \%NonPronominal Subjects and \%Null Pronominal Subjects. Monolinguals produced significantly more Null Pronominal Subjects $(\mathrm{M}=15.0 \%)$ than the bilinguals $(\mathrm{M}=$ $7.2 \%), \mathrm{p}<.001$. The results show a preference for Non-Pronominal occurrences by bilinguals, whereas monolinguals use Null subjects significantly more than bilinguals, as shown in table 4.2:

Table 4.2. Group Statistics

\begin{tabular}{|ll|r|r|r|}
\hline \multicolumn{1}{|c|}{ Group } & \multicolumn{1}{c|}{ N } & \multicolumn{1}{c|}{ Mean } & Std. Deviation \\
\hline pNon_P & 1 mono & 17 & 27.72 & 6.62 \\
& 2 bilingual & 17 & 35.70 & 6.68 \\
\hline pExpl & 1 mono & 17 & 2.12 & 1.99 \\
& 2 bilingual & 17 & 3.05 & 1.95 \\
\hline pNullP & 1 mono & 17 & 14.97 & 5.78 \\
& 2 bilingual & 17 & 7.17 & 4.02 \\
\hline pOvertP & 1 mono & 17 & 55.19 & 5.11 \\
& 2 bilingual & 17 & 54.07 & 8.11 \\
\hline
\end{tabular}

An independent samples T-test confirms these results. Significant differences were found in both Non-Pronominal and Null Pronominal categories, as shown in table 4.3:

Table 4.3. Independent Samples Test

\begin{tabular}{|l|l|l|}
\hline & Levene's Test & t-test for Equality of \\
\hline
\end{tabular}




\begin{tabular}{|c|c|c|c|c|c|}
\hline & \multicolumn{2}{|c|}{$\begin{array}{c}\text { for Equality of } \\
\text { Variances }\end{array}$} & \multicolumn{3}{|c|}{ Means } \\
\hline & $\mathrm{F}$ & Sig. & $\mathrm{t}$ & df & $\begin{array}{l}\text { Sig. }(2- \\
\text { tailed) }\end{array}$ \\
\hline \multirow{2}{*}{$\begin{array}{ll}\text { pNon_P } & \text { Equal variances assumed } \\
& \text { Equal variances not assumed } \\
\end{array}$} & .012 & .913 & -3.497 & 32 & .001 \\
\hline & & & -3.497 & 31.997 & .001 \\
\hline Equal variances assumed & 1.452 & .237 & -1.380 & 32 & .177 \\
\hline Equal variances not assumed & & & -1.380 & 31.988 & .177 \\
\hline Equal variances assumed & 1.510 & .228 & 4.562 & 32 & .000 \\
\hline Equal variances not assumed & & & 4.562 & 28.545 & .000 \\
\hline pOvertP Equal variances assumed & 4.475 & .042 & .480 & 32 & .634 \\
\hline Equal variances not assumed & & & .480 & 26.996 & .635 \\
\hline
\end{tabular}

Chart 1 illustrates the differences found between both groups according to the subject category means. The numbers are divided as: 1) Non-Pronominal, 2) Expletive, 3) Null Pronominal, and 4) Overt Pronominal.

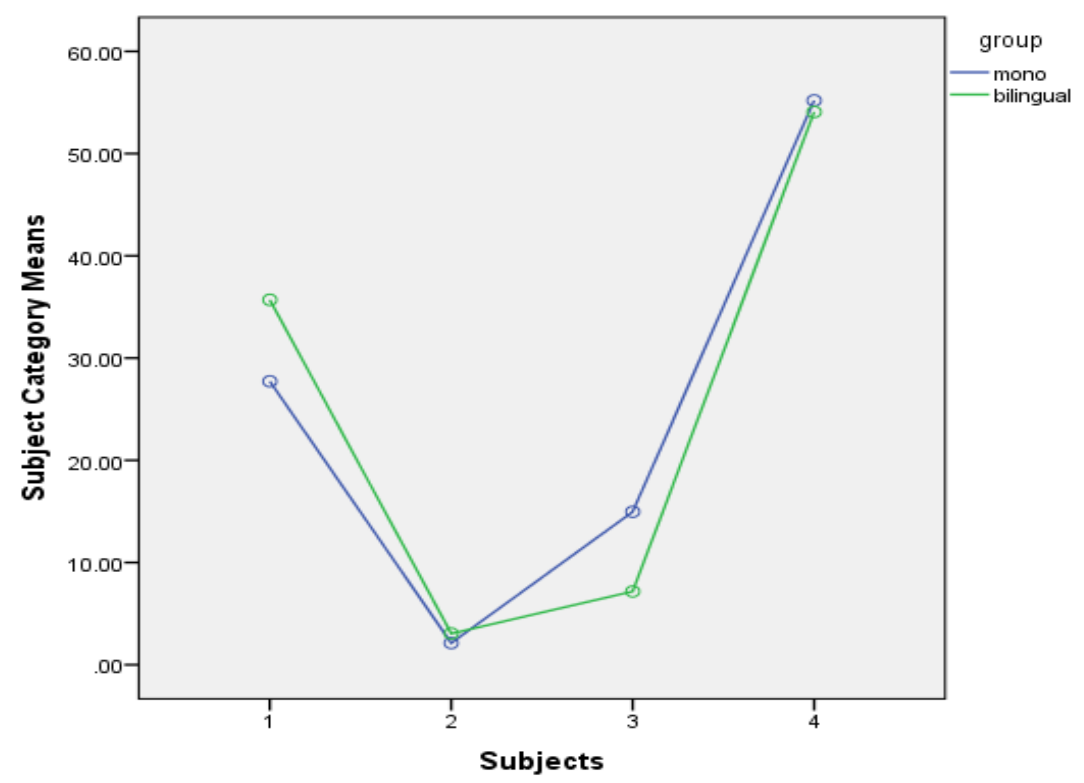

Chart 1. Subject Category Means

The data reveal that monolingual BP speakers who have never left Brazil have a significant preference for usage of null subjects versus overt subjects in comparison with 
speakers of Brazilian Portuguese under the influence of L2 English. Since BP seems to be a language in transition with respect to the behavior of Null Subject, monolinguals are expected to produce more overt subjects than, for instance, monolingual EP speakers, since EP is strictly a NSL. The Interface Hypothesis suggests that syntactic features remain unaffected in the language attrition process, and this analysis shows that bilinguals do behave slightly differently from monolinguals with respect to the usage of null and overt subjects, which raises new questions that are addressed in the following chapter.

\section{Grammaticality judgment task}

The purpose of this task was to analyze differences in the judgment of prompt sentences in both groups with respect to the null subject behavior in matrix and embedded clauses. As described in Chapter 3, fifty sentences were presented to the participants on a computer screen. Participants were then asked to judge how acceptable the sentence sounded to them, by choosing any of the five options presented below the sentence. Below is a screenshot of one of the sentences (s6): 


\section{Ela disse que o pai do Pedro acha que é alta.}

Completamente impossível - Soa estranho -É possível - Completamenteaceitável- Não sei dizer

She said that the father of Pedro thinks that pro is tall (fem.)

Completely impossible - Sounds strange - Possible - Completely Impossible - Don’t know

This sentence is ungrammatical in BP because of a gender clash between pro and the only possible referent. In this case, the null subject of the embedded clause can only refer back to "pai" (father). The word "alta" (tall) is feminine, which explains the ungrammaticality of the sentence. Surprisingly, five participants from each group found this sentence to be acceptable. The ones who judged this sentence as unacceptable fixed it by either adding a feminine overt subject "ela" to the embedded clause, or by changing the gender in "alta" to the masculine "alto", which was predicted.

Only twenty-six out of the fifty sentences were considered for analysis, since the other twenty-four were fillers. Because the Interface Hypothesis suggests that syntactic attrition should not take place, one can infer that there will not be significant differences 
in judgment by both groups in the twenty-six sentences. In fact, most of the sentences are judged similarly by both groups. Differences, however, were found in this analysis. In this section, I will investigate these differences and discuss them in light of the Interface Hypothesis.

The answers given by the participants were grouped into (1) acceptable and (2) unacceptable for this analysis. Hence, "completely unacceptable" and "sounds strange" merged into one category, as well as "is possible" and "completely acceptable". This merging was helpful in order to visualize significant differences. Sentence (s1) will be used to exemplify this change, and the reasons for it. Sentence (s1) is shown below:

(s1) *Ele é possível solicitar fotografias das obras expostas.

It is possible to request photographs of the pieces shown.

Originally, the division in five categories showed results as shown in the table below:

s1 * group Crosstabulation

\begin{tabular}{|lll|r|r|r|}
\hline & & & \multicolumn{2}{|c|}{ group } & \multicolumn{1}{c|}{} \\
\cline { 3 - 6 } & & & 1 mono & 2 bilingual & \multicolumn{1}{c|}{ Total } \\
\hline s1 & 1 comp unacceptable & Count & 4 & 10 & 14 \\
& & $\%$ within group & $23.5 \%$ & $58.8 \%$ & $41.2 \%$ \\
\cline { 2 - 6 } & 2 sounds strange & Count & 8 & 4 & 12 \\
& & $\%$ within group & $47.1 \%$ & $23.5 \%$ & $35.3 \%$ \\
\cline { 2 - 5 } & 3 it's possible & Count & 3 & 3 & 6 \\
& & $\%$ within group & $17.6 \%$ & $17.6 \%$ & $17.6 \%$ \\
\cline { 2 - 5 } & 4 completely acceptable & Count & 2 & 0 & 2 \\
& & $\%$ within group & $11.8 \%$ & $.0 \%$ & $5.9 \%$ \\
\hline Total & & Count & 17 & 17 & 34 \\
& & $\%$ within group & $100.0 \%$ & $100.0 \%$ & $100.0 \%$ \\
\hline
\end{tabular}

The fact that $58.8 \%$ of the bilinguals judged sentence (s1) as completely unacceptable, while only $23.5 \%$ of the monolinguals did, indicates what seems to be a 
significant difference. However, when analyzing the data after the merging, such difference becomes much less significant, as shown below:

\section{s1_2 * group}

\section{Crosstab}

\begin{tabular}{|lll|r|r|r|}
\hline & & \multicolumn{2}{|c|}{ group } & \multirow{2}{*}{ Total } \\
\cline { 3 - 6 } & & & 1 mono & 2 bilingual & \multicolumn{1}{c}{26} \\
\hline s1_2 & 1 comp unc/sounds strg & Count & 12 & 14 & $76.5 \%$ \\
\cline { 2 - 5 } & & $\%$ within group & $70.6 \%$ & $82.4 \%$ & 8 \\
& 2 poss/comp accept & Count & 5 & 3 & $23.5 \%$ \\
\hline Total & $\%$ within group & $29.4 \%$ & $17.6 \%$ & 34 \\
& & Count & 17 & 17 & $100.0 \%$ \\
\hline
\end{tabular}

This chart shows that very few participants in both groups judged this sentence as acceptable, whereas most of them classified it as unacceptable. This justifies the purpose of merging the answers into two distinct categories.

While it is true that no significant differences were detected in most sentences, the few occurrences where syntactic attrition could be an influence are discussed here. Sentence (s25) is one of these occurrences:

(s25) "Como nos custou a despedir aquele empregado!"

How it cost us to fire that employee! (indicating surprise)

The crosstab below shows the judgments for (s25):

\section{s25_2 * group}

\section{Crosstab}

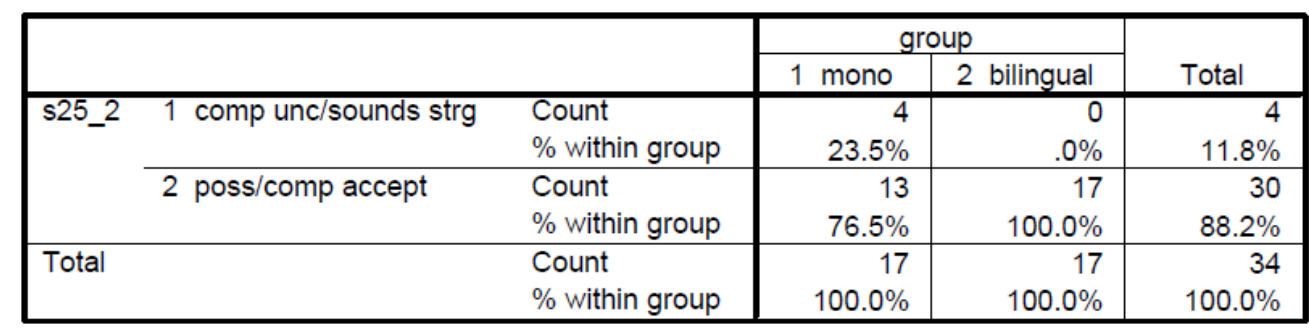


Chi-Square Tests

\begin{tabular}{|c|c|c|c|c|c|}
\hline & Value & df & $\begin{array}{l}\text { Asymp. Sig. } \\
\text { (2-sided) }\end{array}$ & $\begin{array}{l}\text { Exact Sig. } \\
\text { (2-sided) }\end{array}$ & $\begin{array}{l}\text { Exact Sig. } \\
\text { (1-sided) }\end{array}$ \\
\hline Pearson Chi-Square & $4.533^{\mathrm{b}}$ & 1 & .033 & & \\
\hline Continuity Correctiona & 2.550 & 1 & .110 & & \\
\hline Likelihood Ratio & 6.080 & 1 & .014 & & \\
\hline Fisher's Exact Test & & & & .103 & .051 \\
\hline $\begin{array}{l}\text { Linear-by-Linear } \\
\text { Association }\end{array}$ & 4.400 & 1 & .036 & & \\
\hline $\mathrm{N}$ of Valid Cases & 34 & & & & \\
\hline
\end{tabular}

a. Computed only for a $2 \times 2$ table

b. 2 cells $(50.0 \%)$ have expected count less than 5 . The minimum expected count is 2.00 .

The charts above indicate a marginally significant difference between monolingual and bilingual groups on the acceptability of sentence (s25), $\mathrm{p}=.103 .76 .5 \%$ of monolingual speakers thought this was possible or completely acceptable, while all $(100 \%)$ of bilingual speakers did. Such a finding is especially intriguing, since the null expletive is expected to be less common in attrited BP, but the reverse is shown here. However, adding an overt expletive would not make the sentence more acceptable; it would, instead, cause it to be ungrammatical as overt expletives are not a feature present in Brazilian Portuguese. Therefore, I come to the conclusion that such discrepancy in judgments cannot be attributed to influence of L2 English, but perhaps unrelated factors which are irrelevant to this discussion.

Note that it is important that speakers of BP under the influence of English are showing a formal distinction in their grammar between expletive and non-expletive null subjects. The precise analysis of this distinction has been debated in the literature; however, the fact that there is a syntactic contrast between expletive and non-expletive subjects is standardly assumed. Therefore, the fact that speakers of BP under the influence of English treat differentially the expletive from the non-expletive structures 
indicates that their grammar is being selectively affected by the influence of English, which is an important finding.

The same numbers were found in sentence (s48). Sentence (s48) is shown below:

(s48) "Eu disse ao Robertinho que eu gostava de música ao vivo."

I told Robertinho that I liked live music.

The crosstab below shows the participants' judgment of (s48):

\section{Crosstab}

\begin{tabular}{|lll|r|r|r|}
\hline & & & \multicolumn{2}{|c|}{ group } & \multirow{2}{*}{ Total } \\
\cline { 3 - 5 } & & & 1 mono & 2 bilingual & \multicolumn{1}{c|}{4} \\
\hline s48_2 & 1 comp unc/sounds strg & Count & 4 & 0 & $11.8 \%$ \\
\cline { 2 - 5 } & & $\%$ within group & $23.5 \%$ & $.0 \%$ & 30 \\
& 2 poss/comp accept & Count & 13 & 17 & $88.2 \%$ \\
\hline Total & & $\%$ within group & $76.5 \%$ & $100.0 \%$ & 34 \\
& & Count & 17 & 17 & $100.0 \%$ \\
\hline
\end{tabular}

There is also a marginally significant difference between monolingual and bilingual groups on the acceptability of sentence (s48), $\mathrm{p}=.103 .76 .5 \%$ of monolingual speakers judged this sentence as acceptable, while all (100\%) of bilingual speakers did.

\section{Chi-Square Tests}

\begin{tabular}{|c|c|c|c|c|c|}
\hline & Value & df & $\begin{array}{l}\text { Asymp. Sig. } \\
\text { (2-sided) }\end{array}$ & $\begin{array}{l}\text { Exact Sig. } \\
\text { (2-sided) }\end{array}$ & $\begin{array}{l}\text { Exact Sig. } \\
\text { (1-sided) }\end{array}$ \\
\hline Pearson Chi-Square & $4.533^{D}$ & 1 & .033 & & \\
\hline Continuity Correctiona & 2.550 & 1 & .110 & & \\
\hline Likelihood Ratio & 6.080 & 1 & .014 & & \\
\hline Fisher's Exact Test & & & & .103 & .051 \\
\hline $\begin{array}{l}\text { Linear-by-Linear } \\
\text { Association }\end{array}$ & 4.400 & 1 & .036 & & \\
\hline $\mathrm{N}$ of Valid Cases & 34 & & & & \\
\hline
\end{tabular}

a. Computed only for a $2 \times 2$ table

b. 2 cells $(50.0 \%)$ have expected count less than 5 . The minimum expected count is 2.00 . 
Sentence (s48), however, is more interesting to the current analysis, in the sense that it shows a clear case of an overt embedded subject versus a null embedded subject. $23.5 \%$ of the monolingual speakers judged this sentence as unacceptable because of the repetition of the first person singular pronoun "Eu" (I). BP allows for pro in this embedded context, referring back to the subject of the matrix clause. While all bilinguals considered this sentence acceptable with the overt embedded subject "eu", a significant amount of monolinguals found it unacceptable, and changed it by replacing it with a null subject, yielding:

"Eu disse ao Robertinho que Ø gostava de música ao vivo."

While it is true that most monolinguals also judged this sentence as acceptable, it is crucial to point out that no bilinguals considered it mandatory to have a null subject occurrence in the environment in question. This leads to the conclusion that bilinguals under the influence of L2 English do not judge overt embedded subjects as unacceptable due to the fact that such construction is not possible in English:

*I told Robertinho that pro liked live music.

Taking into account that the sample size was thirty-four participants, one can infer that more significant results may have arisen if a similar study had been conducted with a larger number of participants. 


\section{V-DISCUSSION}

This chapter presents, first, a reminder of the aims and key methodological features of this study, followed by a summary of major findings, as well as an evaluation of this study's contributions to the field of linguistics. Recommended implications for further research are presented subsequently.

1. Restatement of aims and methodological approach of study

The main purpose of this research study is to investigate whether bilingual speakers of Brazilian Portuguese under influence of L2 English undergo language attrition from a syntactic perspective. I took into consideration the Interface Hypothesis of Language Attrition (Tsimpli, Sorace, Heycock, Filiaci 2004), which suggests that only interpretable features are affected in a context where bilinguals are immersed in the L2 environment, i.e., living in the country where the L2 is spoken. However, according to this theory, uninterpretable features such as the behavior of words and expressions at the syntactic level should remain unaltered. My study tested whether such claim was, in fact, accurate with respect to the null subject, syntactic feature present in BP but absent in English.

In order to investigate this issue, two tasks were conducted with two groups of BP speakers. The control group consisted of seventeen monolinguals that never left Brazil, and the bilingual group was formed by seventeen speakers who have lived in the US for a period of seven years or longer, to assure some attrition, semantic, syntactic or pragmatic, would indeed take place. An elicited production task was conducted with the intention to analyze the speakers' spontaneous speech and detect how both groups were using the syntactic feature in question. The participants were also given a grammaticality judgment 
task, so that differences in acceptability from both groups could be pointed out. A summary of key findings from both tasks will be presented subsequently.

\section{Summary of findings}

After comparing both groups' spontaneous production, the following numbers were obtained from this analysis: $78.6 \%$ of the pronominal subjects produced by the monolinguals were overt, and $21.4 \%$ null. In contrast, the bilingual group produced $88.2 \%$ overt pronominal subjects and only $11.8 \%$ null subjects. This slight difference in behavior is not significant enough to affirm that syntactic attrition took place. I do believe, however, that a study conducted with a larger sample size could potentially bring this slight discrepancy in pattern to a more significant level. The results of this task do not negate the validity of the Interface Hypothesis since both groups behaved similarly with respect to the spontaneous production of matrix and embedded null subjects.

The grammaticality judgment task yielded results that show little or no difference between both groups in most of the sentences presented to the participants. Sentence (s48) is an example that suggests that bilinguals prefer a construction with an overt embedded subject, like in English. Sentence (s48) is suggestive that there is syntactic attrition. Considering the sample size used for this study, the findings of this task were not significant enough to counter-argue the Interface Hypothesis. A pattern, however, is seen where syntactic discrepancies take place. Investigating this pattern more closely could be a way to test this theory in more depth, which I will readdress further as implications for further research. 
3. Evaluation of study's contributions

Language attrition from several different linguistic perspectives has been intriguing researchers for many years. Theories such as the Interface Hypothesis, for example, are of extreme importance to the study of language acquisition, since they provide us with an innovative view of previous research findings. The findings presented in this study are relevant to the field of language acquisition in the sense that, although they did not disprove a theory, they suggest it could be disproven in the future if taken into account the limitations encountered. The most obvious limitation in this research was that of a small sample size. It certainly would have been easier to find bilingual participants if the study had been conducted in an area with a larger Brazilian community, which is not the case in Miami. Finding enough monolinguals to generate more significant results for this study would require a longer stay in Brazil, which was not possible at the time the data were collected.

4. Recommendations for further research

Although the results were not significant enough to counter-argue the Interface Hypothesis, they certainly have provided further evidence suggesting that syntactic attrition could take place given certain contexts. Data from monolingual European Portuguese speakers were collected using the same method over the summer of 2011. Below is an excerpt from the elicited production task by one of the participants:

"Então a Mônica ia a passear, encontrou uma poça de lama no caminho, olhou pra poça de lama e viu o Cebolinha à frente da poça. Queria chegar até o Cebolinha só que não queria pisar a lama e então o que ela pensou foi que a melhor solução seria pedir ao Cebolinha para despir a t-shirt e pôr por cima da poça de lama para 
poder fazer uma espécie de uma ponte para ela poder passar. Tentou chamar a atenção de várias maneiras mas como ele estava a comer um chupa-chupa, não se percebeu da presença dela. Quando se percebeu da presença dela, ficou admirado. Ela disse que queria ir ter com ele, para o pé dele, e mas disse que não queria pisar a poça. Disse-lhe que se ele pusesse a t-shirt a tapar-lhe a poça que ela lhe oferecia um beijinho ou coisa parecida."

So Monica went for a walk, found a mud puddle on the road, looked at the mud puddle and saw the puddle in front of Cebolinha. Ø wanted to get to Cebolinha but Ø did not want to step on the mud and then what she thought was the best solution would be to ask Cebolinha to take off the shirt and put over the mud puddle in order to make a sort of a bridge so she could pass. Ø tried to draw attention in many ways but as he was eating a lollipop, did not notice her presence. When $\varnothing$ noticed her presence, $\varnothing$ was amazed. She said she wanted to get closer to him, and but did not want to step on the puddle. Ø told him that if he put the t-shirt to cover her she puddle she would offer him a kiss or something.' As shown in the excerpt above, EP is a language where the null subject remains a strong syntactic feature. A similar study comparing EP and English may yield results that could show evidence against the Interface Hypothesis. Another study comparing different syntactic features that are present in one language but lacking in another would surely be relevant to the language acquisition field and certainly contribute to innovative discoveries in Linguistics. 


\section{LIST OF REFERENCES}

Arteaga, D. (1994). "Impersonal constructions in Old French". Issues and Theory in Romance Linguistics. Selected Papers from the Linguistic Symposium on Romance Languages XIII, Ed. M. L. Mazzola. Washington: Georgetown University Press. 141-157.

Barbosa P., Duarte M. E. L., and Kato M. (2005) Null Subjects in European and Brazilian Portuguese. Journal of Portuguese Linguistics.

Bellugi, U. (1967). The Acquisition of Negation. Unpublished doctoral dissertation. Harvard University.

Bialystok, E. (2001). Bilingualism in Development. Cambridge: Cambridge University Press.

Brandi, L., \& Cordin, P. (1989). Two Italian dialects and the null subject parameter. In O. Jaeggli \& K. Safir (eds.) The null subject parameter.Dordrecht: Kluwer, 111-142.

Brown, R. (1973) A First Language: the Early Stages. Cambridge, Mass.: Harvard University Press.

Chomsky, N. (1977) On wh-Movement. In Formal Syntax (P. Culicover, T. Wasos and A. Akmajian, editors), pp. 71-132. New-York: Academic Press.

Chomsky, N. (1981) Lectures on Government and Binding. Dordrecht: Foris

Cook, V. J. (2003). Changing the first language in the L2 user's mind. Draft of Intro to L2 effects on the L1. Online: http://homepage.ntlworld.com/Vivian. c/writings/papers/fxintro.htm

Cook, V.J. \& Newson, M. (2007). Topics in language acquisition. In Chomsky's Universal Grammar: An Introduction, 3rd Ed Wiley-Blackwell

Cuza, A. (2008). The L2 acquisition and L1 attrition of the interpretation and use of aspectual properties in Spanish among English-speaking L2 learners and longterm Spanish Immigrants. Doctoral Dissertation. University of Toronto. Canada.

Cuza, A. (2009). Incomplete acquisition and L1 attrition of subject verb inversion in Spanish optionality outside the interfaces. Linguistic Symposium on Romance Linguistics (LSRL33). University of Arizona. March 2009.

Cuza, A. (2010). The L1 attrition of the Spanish present tense. Hispania, 93.2: 256-272

Depiante, M. and Thompson, E. (2010). Preposition Stranding and Ellipsis in Heritage 
Speakers of Spanish. Presented at Bilingual Workshop in Theoretical Linguistics 14, University of Toronto, December, 2010.

De Sousa, Maurício. (2010) No meio do caminho tinha uma poça de lama. Almanaque da Mônica 21: 4-20. Editora Panini Comics.

Duarte, M. E. L. (1993) Do pronome nulo ao pronome pleno: a trajetória do sujeito no português do Brasil. In Português Brasileiro: Uma viagem diacrônica(Homenagem a Fernando Tarallo) (I. Roberts \& M. A Kato, editors), pp. 107-128.Campinas: Editora da UNICAMP.

Duarte, M. E. L. (1995) A Perda do Princípio "Evite pronome" no Português Brasileiro. Ph.D. Dissertation, UNICAMP.

Duarte, M. E. L. (1998) Left-Dislocated Subjects and Parametric Change in Brazilian Portuguese. Proceedings of the 16th International Congress of Linguists. Paris. CD Syntax, 219.

Duarte, M. E. L. (2000) The loss of the 'Avoid Pronoun' principle in Brazilian Portuguese. In Kato \& Negrão (editors), pp. 17-36.

Ferreira, M. B. (2000). Argumentos Nulos em Português Brasileiro. M.A. thesis, Universidade Estadual de Campinas.

Ferreira, M. B. (2004). Hyperraising and Null Subjects in Brazilian Portuguese. MIT Working Papers in Linguistics 47: Collected Papers on Romance Syntax, 57-85.

Figueiredo Silva, C. (1996). A Posição do Sujeito no Português Brasileiro: Frases Finitas e Infinitivas. Campinas: Editora da UNICAMP.

Gürel, A. (2004). Selectivity in L2-induced attrition: A psycholinguistics account. Journal of Neurolinguistics, 17, 53-78.

Hornstein, N. (2001). Move! A Minimalist Theory of Construal. Oxford: Blackwell.

Hyams, N. M. (1986). Language acquisition and the theory of parameters. D. Reidel Pub. Co

Hyams, N. M. (1989).The Null Subject Parameter in Language Acquisition. In O. Jaeggli \& K. Safir (eds.) The null subject parameter.Dordrecht: Kluwer.

Isabelli, C. (2004). The acquisition of the null subject parameter properties in SLA: Some effects of positive evidence in a naturalistic learning context. Hispania 87: 150-162. 
Jaeggli, O. (1984) Subject extraction and the null subject parameter. NELS 14, 132-153.

Jaeggli, O. \& Safir, K. (1989). The Null Subject Parameter and Parametric Theory. In: Jaeggli, O. \& Safir, K. (eds.) The Null Subject Parameter. Dordrecht: Kluwer, pp.2391.

Jamshidiha, H. \& Marefat, H. (2005). L1 Persian Attrition: A Study of Adult Bilinguals. Unpublished MA Thesis، University of Tehran، Iran

Kato, M. A. (1996) Português Brasileiro falado: aquisição em contexto de mudança lingüística. In Actas do Congresso Internacional sobre o Português, (I. Duarte \& I. Leiria, editors), vol II, pp. 211-237.

Kato, M. A. (1999) Strong pronouns and weak pronominals in the null subject parameter. Probus, 11(1), 1-37.

Kato, M. A. (2000) The partial pro-drop nature and the restricted VS order in Brazilian Portuguese. In: Kato \& Negrão (editors), pp. 223-258.

Kato, M. A. and Negrão E. V.(eds.). (2000). Brazilian Portuguese and the Null Subject Parameter. Madrid \& Frankfurt am Main: Iberoamericana \& Vervuert.

Köpke, B. (2002). Activation thresholds and non-pathological L1 attrition. In F. Fabbro (Ed.), Advances in the Neurolinguistics of Bilingualism. Essays in Honor of Michel Paradis (pp.119-142). Undine: Forum.

Köpke, B. (2004). Neurolinguistic aspects of attrition. Journal of Neurolinguistics, 17, 330.

Köpke, B. \& Schmid, M. (2004). Language attrition: The next phase. In M. S. Schmid, B. Köpke, M. Keijzer and L. Weilemar (Eds.), First language attrition: Interdisciplinary perspectives on methodological issues (pp. 1-47). Amsterdam: John Benjamins.

Köpke, B., M.S. Schmid, M. Keijzer \& S. Dostert (Eds.). (2007). Language Attrition: Theoretical perspectives. Amsterdam: John Benjamins.

Martins, A. M. and Nunes J. (2005). Raising Issues in Portuguese. Journal of Portuguese Linguistics 4:53-77.

Martins, A. M. and Nunes J. (2010). Syntactic change as chain reaction: The emergence of hyper-raising in Brazilian Portuguese. [Selected papers from DIGS 9, Trieste 2006], ed. by Paola Crisma \& Giuseppe Longobardi. Oxford University Press

Modesto, M. (2000). On the identification of null Arguments. Doctoral dissertation, University of Southern California. 
Montalbetti, M. (1984). After Binding: On the Interpretation of Pronouns. Unpublished doctoral dissertation, MIT.

Montrul, S. (2002). Incomplete acquisition and attrition of Spanish tense/aspect distinctions in adult bilinguals. Bilingualism: Language and Cognition 5, 39-68.

Newmeyer, F. (2005). Possible and probable languages: A generative perspective on linguistic typology. Oxford: Oxford University Press.

Pacheco, S. \& S. Flynn (2006). Syntax-Pragmatics Interface: Brazilian-Portuguese L2 Acquisition of English. In N. Sagarra \& A. J. Toribio (eds.), Selected Proceedings of the 9th Hispanic Linguistics Symposium, 229-240. Cascadilla Proceedings Project, Somerville, MA.

Perlmutter, D. (1971). Deep and Surface Structure Constraints in Syntax, Holt, Rinehart \& Winston, New York.

Pires, A. (2002). Cuebased change: Inflection and subjects in the history of Portuguese infinitives. In D. Lightfoot (Ed.), Syntactic effects of morphological change, (pp.143 - 159). Oxford: Oxford University Press.

Pires, A. (2006). The minimalist syntax of defective domains: Gerunds and infinitives. Amsterdam: John Benjamins.

Raposo, E. \& Uriagereka. J. (1990). Long distance case assignment. Linguistic Inquiry 21: 505-557.

Rodrigues, C. (2002). Morphology and Null Subjects in Brazilian Portuguese. Syntactic Effects of Morphological Change, ed. by D. Lightfoot. Oxford \& New York: Oxford University Press. 160-178.

Rodrigues, C. (2004). Impoverished morphology and A-movement out of Case domains. Doctoral dissertation, University of Maryland.

Rothman , J. (2007). Heritage speaker competence differences, language change and Input type: Inflected infinitives in heritage Brazilian Portuguese . International Journal of Bilingualism, 11 ,

Rothman, J. \& Iverson, M. (2007). The Syntax of Null Subjects in L2 Spanish: Comparing Two L2 Populations Under Different Exposure. RESLA 20: 185-214

Seliger, H. W. (1989). Deterioration and creativity in childhood bilingualism. In K. Hyltenstam and L.K. Obler (Eds.), Bilingualism across the lifespan (pp.173-184). Cambridge: Cambridge University Press. 
Seliger, H. W. (1991). Language attrition, reduced redundancy, and creativity. In H.W. Seliger and R.M. Vago (Eds.), First Language Attrition (pp. 227-240). Cambridge: Cambridge University Press.

Seliger, H. W. (1996). Primary language attrition in the context of bilingualism. In W. C. Ritchie \& TEJK Bhatia (Eds.), Handbook of second language acquisition (pp. 606625). London: Academic Press.

Seliger, H. W. and Vago, R.M. (Eds.). (1991). First language attrition. Cambridge: Cambridge University Press.

Silva-Corvalán, C. (1991). Cross-generational bilingualism: theoretical implications of language attrition. In Cross Currents in Second Language Acquisition and Linguistic Theory, Huebner, T. and C. A. Ferguson (eds.), 325 ff.

Sorace, A. \& Filiaci, F. (2006), Anaphora resolution in near-native speakers of Italian, Second Language Research 22(3), 339-368. Sorace, A. (2000). Differential effects of attrition in the L1 syntax of L2 near-native speakers. In Proceedings of the 24th Boston University Conference on Language Development (pp.719-725). Somerville, MA: Cascadilla Press.

Sorace, A. (2005). Syntactic optionality at interfaces. In L. Cornips and K. Corrigan (Eds.), Syntax and variation: reconciling the biological and the social (pp. 46-111). Amsterdam: John Benjamins Publishing Company.

Tsimpli, I. (2007). First language attrition from a minimalist perspective: Interface vulnerability and processing effects. In Köpke et al. (eds.), 83-98.

Tsimpli, I., Sorace, A., Heycock, C. and Filiaci, F. (2004). First language attrition and syntactic subjects: A study of Greek and Italian near-native speakers of English. International Journal of Bilingualism 8(3): 257-277.

Villa-García, J. (2007). The Null Subject Parameter and the Classical Analysis of pro. In: Aspects of the Morphosyntax of Finite Null Subjects in Romance. Master's Disssertation. 2: 12-28. University of Essex. 


\section{APPENDIX}

\section{Questionnaire -Monolinguals}

Nome:

E-mail para contato:

Data de Nascimento:

Profissao:

Local de Nascimento:

Grau de Instrucao:

Escolas que frequentou e datas:

de

a

de

a

de

a

de

a

Morou em outro estado brasileiro?
Se sim, onde?

de

de

a

Se sim, onde? de a de a

Recebeu alguma instrucao formal no exterior? Qual?

Linguas a que foi exposto fora do Brasil:

\section{Historico Linguistico do Sujeito}

Linguas faladas alem de Portugues Brasileiro (descreva em detalhes - idade em que foi exposto, como foi exposto)

Em casa (mae, pai, avos...)

$\mathrm{Na}$ escola (anos e nivel)

Entre parentes proximos

Outros contextos

Nivel de competencia em linguas adquiridas alem de Portugues Brasileiro: 
Historico Familiar

$\underline{\text { Mae }}$

Local de nascimento:

Onde morou desde o nascimento (em outros estados ou paises)

Grau de Instrucao:

Profissao:

Linguas faladas/estudadas:

$\underline{\text { Pai }}$

Local de nascimento:

Onde morou desde o nascimento (em outros estados ou paises)

Grau de Instrucao:

Profissao:

Linguas faladas/estudadas:

\section{Historico de outros adultos na casa onde mora}

Avo, avo, etc.:

Local de nascimento:

Onde morou desde o nascimento (em outros estados ou paises)

Grau de Instrucao:

Profissao:

Linguas faladas/estudadas: 


\section{Questionnaire - Bilinguals}

Nome:

Data de Nascimento:

No Brasil

Local de Nascimento:

Grau de Instrucão:

Escolas que frequentou e datas:

de

de

de

a

de

a

Se sim, onde?

de

a

Se sim, onde?

de

Recebeu alguma instrucão formal no exterior? Qual?

Linguas a que foi exposto fora do Brasil:

\section{Nos Estados Unidos}

Quando chegou aos Estados Unidos?

Em que parte do pais morou e em que datas?

Grau de instrucão:

Escolas que frequentou e datas:

de

a

de

a

de

a

de 
Historico Linguistico do Sujeito

\section{No Brasil}

Linguas faladas alem de Portugues Brasileiro (descreva em detalhes - idade em que foi exposto, como foi exposto)

Em casa (mãe, pai, avos...)

Na escola (anos e nivel)

Entre parentes proximos

Outros contextos

Nivel de competencia em linguas adquiridas no Brasil alem de Portugues Brasileiro:

\section{Nos Estados Unidos}

Linguas faladas alem de Portugues Brasileiro (descreva em detalhes - idade em que foi exposto, como foi exposto)

Em casa (mãe, pai, avos...)

Na escola (anos e nivel)

Entre parentes proximos

Outros contextos

Nivel de competencia em linguas adquiridas nos E.U.A. alem de Portugues Brasileiro:

\section{Historico Familiar}

Mãa

Local de nascimento:

Onde morou desde o nascimento (em outros estados ou paises) 
Linguas faladas/estudadas no Brasil:

Idade ao chegar aos E.U.A.:

Profissão nos E.U.A.:

Linguas faladas/estudadas nos E.U.A:

Educacão nos E.U.A. (em que idiomas):

$\underline{\text { Pai }}$

Local de nascimento:

Onde morou desde o nascimento (em outros estados ou paises)

Grau de Instrucão:

Profissao:

Linguas faladas/estudadas no Brasil:

Idade ao chegar aos E.U.A.:

Profissão nos E.U.A.:

Linguas faladas/estudadas nos E.U.A:

Educacão nos E.U.A. (em que idiomas):

\section{Historico de outros adultos na casa onde mora}

$\underline{\text { Avo, avo, etc.: }}$

Local de nascimento:

Onde morou desde o nascimento (em outros estados ou paises)

Grau de Instrucão:

Profissão:

Linguas faladas/estudadas no Brasil:

Idade ao chegar aos E.U.A.:

Profissão nos E.U.A.:

Linguas faladas/estudadas nos E.U.A:

Educacão nos E.U.A. (em que idiomas): 